\title{
Climatic Controls on a Holocene Mercury Stable Isotope Sediment Record of Lake Titicaca
}

\author{
Martin Jiskra,* Stéphane Guédron,* Julie Tolu, Sherilyn C. Fritz, Paul A. Baker, and Jeroen E. Sonke
}

Cite This: ACS Earth Space Chem. 2022, 6, 346-357

Read Online

ABSTRACT: Mercury $(\mathrm{Hg})$ records in sediment archives inform past patterns of $\mathrm{Hg}$ deposition and the anthropogenic contribution to global $\mathrm{Hg}$ cycling. Natural climate variations complicate the interpretation of past $\mathrm{Hg}$ accumulation rates (HgARs), warranting additional research. Here, we investigated $\mathrm{Hg}$ stable isotopes in a ca. 8k year-long sediment core of Lake Titicaca and combined isotopic data with organic biomarkers and biogeochemical measurements. A wet period in the early Holocene (8000-7300 $\mathrm{BP}$ ) induced strong watershed erosion, leading to a high $\mathrm{HgAR}$ $\left(20.2 \pm 6.9 \mu \mathrm{g} \mathrm{m}^{-2}\right.$ year $\left.^{-1}\right)$, which exceeded the 20th century $\operatorname{HgAR}\left(8.4 \pm 1.0 \mu \mathrm{g} \mathrm{m}^{-2}\right.$ year $\left.^{-1}\right)$. Geogenic $\mathrm{Hg}$ input dominated during the early Holocene $\left(f_{\text {geog }}=79 \%\right)$ and played a minor role

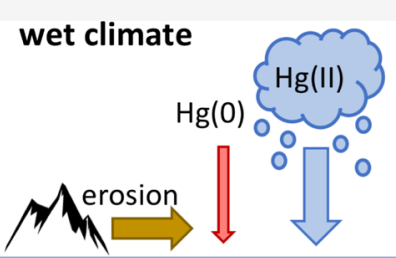

lake dry climate<smiles>CCCCC</smiles>

\begin{tabular}{ll|l}
\hline sediment high $\Delta^{200} \mathrm{Hg}$ & low $\Delta^{200} \mathrm{Hg}$ \\
\hline
\end{tabular}
during the mid- to late Holocene ( $4500 \mathrm{BP}$ to present; $f_{\text {geog }}=20 \%$ ) when atmospheric $\mathrm{Hg}$ deposition dominated. Sediment $\Delta^{200} \mathrm{Hg}$ values and the absence of terrestrial lignin biomarkers suggest that direct lake uptake of atmospheric $\mathrm{Hg}(0)$, and subsequent algal scavenging of lake $\mathrm{Hg}$, represented an important atmospheric deposition pathway (42\%) during the mid- to late Holocene. During wet episodes of the late Holocene (2400 BP to present), atmospheric $\mathrm{Hg}$ (II) deposition was the dominant source of lake sediment $\mathrm{Hg}$ (up to $82 \%$ ). Sediment $\Delta^{199} \mathrm{Hg}$ values suggest that photochemical reduction and re-emission of $\mathrm{Hg}(0)$ occurred from the lake surface. $\mathrm{Hg}$ stable isotopes show promise as proxies for understanding the history of $\mathrm{Hg}$ sources and transformations and help to disentangle anthropogenic and climate factors influencing HgAR observed in sediment archives.

KEYWORDS: $\mathrm{Hg}$ stable isotopes, climate variations, Holocene, atmospheric deposition, erosion, sediment archive

\section{INTRODUCTION}

Natural atmospheric mercury $(\mathrm{Hg})$ cycling on geological timescales is thought to be driven by volcanic ${ }^{1,2}$ emissions and soil and ocean (re-)emissions. The natural $\mathrm{Hg}$ cycle has been perturbed by anthropogenic activities, such as mining and smelting, for millennia. ${ }^{3}$ Industrialization led to a surge in global anthropogenic $\mathrm{Hg}$ emissions mainly through $\mathrm{Hg}$, silver, and gold production and $\mathrm{Hg}$ release from coal combustion, with a recent study estimating that $73 \%$ of all-time anthropogenic emissions occurred after $1850 .{ }^{4}$ In the Northern Hemisphere $(\mathrm{NH})$, atmospheric $\mathrm{Hg}(0)$ concentrations and $\mathrm{Hg}$ (II) deposition have decreased significantly since monitoring started in the 1970 s. ${ }^{5,6}$ This decrease is attributed to a reduction in anthropogenic $\operatorname{Hg}(0)$ emissions related to air pollution control measures in coal-fired power plants and incinerators. ${ }^{5}$ Changes in natural drivers, such as the effect of increasing gross terrestrial primary production ${ }^{7}$ or precipitation intensity $^{8}$ over the last century, may also have affected regional and global $\mathrm{Hg}$ deposition superimposed on the anthropogenic emission signal. Understanding how anthropogenic and natural factors affect global $\mathrm{Hg}$ cycling improves the quality of model predictions of future $\mathrm{Hg}$ burden under different anthropogenic emission and climate change scenarios.

Historical archives, such as lake sediment, peat and ice cores, provide invaluable records of past atmospheric $\mathrm{Hg}$ accumulation rates (HgARs $)^{9-12}$ and may serve to disentangle climate and anthropogenic drivers in $\mathrm{Hg}$ cycling. In the Southern Hemisphere ( $\mathrm{SH})$, the first anthropogenic impacts on $\mathrm{Hg}$ accumulation in sediments from mining and smelting were documented $>3 \mathrm{k}$ years ago ${ }^{3,13}$ and intensified after the 16th century during Spanish colonization. ${ }^{14,15}$ Climate-related variations in $\mathrm{Hg}$ deposition observed in a Holocene sediment record from Patagonia suggested that during dry periods, enhanced lake primary productivity and lower $\mathrm{Hg}$ evasion led to higher HgARs. ${ }^{16}$ In the central Andes, a recent study reported that the $\mathrm{HgAR}$ in a $13.5 \mathrm{k}$ year sediment record was

Received: September 2, 2021

Revised: December 10, 2021

Accepted: December 20, 2021

Published: January 19, 2022 
mainly driven by precipitation, with higher deposition rates during wet intervals. ${ }^{17,18}$

$\mathrm{Hg}$ stable isotopes have recently been measured in paleoenvironmental archives and have been used to trace sources and biogeochemical transformations of $\mathrm{Hg}$ in the environments studied. ${ }^{6,13,19}$ Atmospheric $\mathrm{Hg}(0)$ and $\mathrm{Hg}(\mathrm{II})$ in precipitation have characteristic even-mass $\mathrm{Hg}$ stable isotope anomalies $\left(\Delta^{200} \mathrm{Hg}\right.$ and $\left.\Delta^{204} \mathrm{Hg}\right),{ }^{20-25}$ allowing the quantification of atmospheric deposition pathways to earth surface reservoirs. ${ }^{6,24,26}$ Based on the $\delta^{202} \mathrm{Hg}$ and $\Delta^{200} \mathrm{Hg}$ signatures in vegetation and soils, an increasing number of studies have shown that vegetation uptake of atmospheric $\mathrm{Hg}(0)$ represents the dominant deposition pathway to terrestrial ecosystems, exceeding direct deposition of atmospheric $\mathrm{Hg}(\mathrm{II})$ in precipitation. $^{23-25,27-29}$ The isotope signal of atmospheric $\mathrm{Hg}(0)$ uptake by vegetation in terrestrial ecosystems has been traced in $\mathrm{Hg}$ transported in surface runoff, ${ }^{30,31}$ in ocean and lake sediments, ${ }^{32-35}$ and in biota. ${ }^{36}$ Postdeposition processes, in particular, photoreduction of $\mathrm{Hg}(\mathrm{II})$ to gaseous $\mathrm{Hg}(0)$ that can be subjected to re-emission, can produce characteristic odd-mass $\mathrm{Hg}$ stable isotope anomalies (i.e., $\Delta^{199}$ and $\Delta^{201}$ $\mathrm{Hg}){ }^{37,38}$

$\mathrm{Hg}$ stable isotope records of lake sediments have shown promise in the reconstruction of the history of anthropogenic pollution. ${ }^{8,13,19,39-41}$ A common pattern in many sediment cores is the increase of $\Delta^{199} \mathrm{Hg}$ and $\Delta^{200} \mathrm{Hg}$ with industrialization from the 1850 s to present. Lepak et al. ${ }^{41}$ suggested that this increase in $\Delta^{199} \mathrm{Hg}$ and $\Delta^{200} \mathrm{Hg}$ in the sediment reflects a change in global atmospheric $\mathrm{Hg}$ stable isotope signatures of anthropogenic emissions. Other authors suggested that changes in redox transformations in the atmosphere and within the lake water, ${ }^{40}$ or decreases in ice coverage, ${ }^{39}$ caused the observed variations. Another central question emerging from recent studies is the degree to which the natural $\mathrm{Hg}$ isotope baseline varies between different lake sediments. ${ }^{8,41}$ Lepak et al. ${ }^{41}$ suggested that the baseline $\mathrm{Hg}$ stable isotope signature is mainly controlled by watershed characteristics, with large watershed to lake surface areas receiving a higher proportion of litterfall-derived atmospheric $\mathrm{Hg}(0)$, and therefore lower $\delta^{202} \mathrm{Hg}, \Delta^{199} \mathrm{Hg}$, and $\Delta^{200} \mathrm{Hg}$.

Lake Titicaca is a sentinel of climate change in the southern tropical Andes and has experienced large fluctuations of the lake level over the Holocene due to changes in precipitation regimes. ${ }^{18,42,43}$ We hypothesize that $\mathrm{Hg}$ stable isotope records of lake sediment archives can provide insight into temporal variations of atmospheric deposition sources, sediment transfer from the lake catchment area, and in-lake $\mathrm{Hg}$ transformations, thereby providing information on climate and anthropogenic drivers of $\mathrm{Hg}$ cycling. In this study, we combined $\mathrm{Hg}$ stable isotopes and $\mathrm{Hg}$ accumulation rates from a sediment core collected in the southern Lake Titicaca sub-basin along with various inorganic and organic biomarkers to investigate the controls of natural climate variations in the Southern Andes on $\mathrm{Hg}$ accumulation over the Holocene.

\section{MATERIALS AND METHODS}

2.1. Lake Titicaca: Climatic, Geological, and Ecological Settings. Lake Titicaca is the most important water resource of the high-altitude Andean Altiplano. It comprises two separate basins: a large lake named "Lago Mayor" (7131 $\mathrm{km}^{2}$; mean depth $=100 \mathrm{~m}$; max depth $\left.=285 \mathrm{~m}\right)$ and a smaller lake named "Lago Menor" (1428 $\mathrm{km}^{2}$; mean depth = $9 \mathrm{~m}$; max depth Chua trough $=40 \mathrm{~m}) .{ }^{44}$ The two basins are connected by the $1 \mathrm{~km}$ wide Strait of Tiquina, which has a sill depth of $\sim 35 \mathrm{~m}$ below modern lake level. ${ }^{44,45}$ Thus, the two basins of Lake Titicaca are separated when the water level decreases by $35 \mathrm{~m}$.

The lake has a single outlet, the Río Desaguadero, which drains the southern end of Lago Menor to the central Altiplano. Lake Titicaca receives water mainly from precipitation, and its hydrological export is dominated by evaporation ( $\sim 95 \%$ ), whereas river outflow represents only $\sim 5 \%$ of water loss. The water is alkaline, with a salinity close to $1 \mathrm{~g} \mathrm{~L}^{-1}$, and has an anion balance dominated by sulfates. ${ }^{44}$ Owing to its high-altitude location (3809 $\mathrm{m}$ a.s.l.), some of the lake's physicochemical characteristics are unusual, with a dissolved oxygen concentration of around $60 \%$ of the saturation at the sea level, and extremely high variability in diel UV radiation (i.e., between $800-1150$ and $24-48 \mathrm{~kJ} \mathrm{~m}^{-2}$ for UVA and UVB, respectively). ${ }^{46,47}$

More than $70 \%$ of rainfall occurs during the austral summer (i.e., between December and March) when moist air from the Amazon is uplifted to the Altiplano and produces convective rainfall. Centennial to millennial-scale shifts of the South American summer monsoon (SASM) have occurred in the past $400 \mathrm{k}$ years. ${ }^{43,48-50}$ The near-continental scale SAMS forced in part by the Atlantic Meridional Overturning Circulation (AMOC), ${ }^{18,51-54}$ brings moisture to the Altiplano and has resulted in large changes in Lake Titicaca water levels. ${ }^{55}$ For example, a major drought occurred during the mid-Holocene (i.e., between $7 \mathrm{k}$ and $4 \mathrm{k}$ year $\mathrm{BP}$ ), which resulted in an $\sim 80 \mathrm{~m}$ decrease in the water level of Lago Major ${ }^{42,56,57}$ and led the southern shallow basin to almost dry out. $^{58}$ Glaciers provide a relatively small contribution to the water mass balance of Lake Titicaca and their importance was relatively constant over the study period with a maximum glacier extent of $30 \%$ larger than at present. $^{59}$

2.2. Sediment Core Collection and Sample Processing. A $161 \mathrm{~cm}$ long gravity core, designated Chua 1 $\left(\mathrm{S} 16^{\circ} 12.917^{\prime}, \mathrm{W}^{\circ} 68^{\circ} 46.111^{\prime}\right)$, was collected in January 2014 in the center of the Chua trough in Lago Menor at $38 \mathrm{~m}$ water depth using a UWITEC corer equipped with $63 \mathrm{~mm}$ diameter PVC tubes. A chronological framework was established through the combination of radionuclides $\left({ }^{201} \mathrm{~Pb} /{ }^{137} \mathrm{Cs}\right)$ and radiocarbon $\left({ }^{14} \mathrm{C}\right)$ dates that have been previously published ${ }^{60}$ and is reproduced in Figure S2. The core was sliced with high resolution (i.e., 5-10 $\mathrm{mm}$ slices depending on the lithology) to the base of the core. In each slice, a precise sediment volume $\left(3.8 \mathrm{~cm}^{3}\right)$ of sediment was collected for determining the water content and the dry bulk density (DBD) from the difference in weight before and after freeze-drying. The retrieved freezedried sediment samples were then crushed to obtain a grain size smaller than $63 \mu \mathrm{m}$ for the measurements of total $\mathrm{Hg}$ and its stable isotopes, major and trace elements, total organic carbon $\left(C_{\text {org }}\right)$ and its stable isotope composition $\left(\delta^{13} C_{\text {org }}\right)$, and organic biomarkers.

2.3. Mercury Analysis. Total mercury concentrations ( $\mathrm{THg}$ ) were determined by atomic absorption spectrophotometry using an AMA 254 analyzer (Altec). ${ }^{61,62}$ Concentrations obtained for repeated analyses of the certified reference material MESS-3 were $90.3 \pm 2.1 \mathrm{ng} \mathrm{g}^{-1}(n=22)$ and agreed with the published certified $\mathrm{Hg}$ concentrations of $91 \pm 0.9 \mathrm{ng} \mathrm{g}^{-1}$. The detection limit was $0.005 \mathrm{ng} \mathrm{g}^{-1}$ for $\mathrm{THg}$ and blanks were $20 \pm 5 \mathrm{pg}(n=65)$. $\mathrm{Hg}$ accumulation rates (HgARs) were calculated as the product of $\mathrm{DBD}$, sedimentation rate, and $\mathrm{THg}$ concentration. 
2.4. Hg Stable Isotope Analysis. $\mathrm{Hg}$ stable isotope measurements were performed at the Observatoire MidiPyrenees by cold-vapor generation inductively coupled plasma multicollector mass spectrometry (CV-MC-ICP-MS, ThermoFinnigan Neptune) according to previously published protocols. ${ }^{63}$ Sediment samples were preconcentrated by combustion in a double-stage tube furnace and trapping in an acid solution (IAR, 4.2 $\mathrm{N}_{\mathrm{HNO}_{3}}, 1.2 \mathrm{~N} \mathrm{HCl}$ ). ${ }^{64}$ Sample yields were calculated by comparing $\mathrm{Hg}$ concentrations of the trapping solutions to solid-phase $\mathrm{THg}$ measurements and were $90 \pm$ $15 \%(n=33)$. Mass-dependent fractionation (MDF) is reported as small delta $\left(\delta^{x x x} \mathrm{Hg}\right)$ in per mil $(\% o)$ deviation from the NIST $3133 \mathrm{Hg}$ bracketing standard

$$
\delta^{x x x} \mathrm{Hg}=\left({ }^{x x x / 198} \mathrm{Hg}_{\text {sample }} /{ }^{x x x / 198} \mathrm{Hg}_{\text {NIST3133 }}-1\right) \times 10^{3}
$$

where " $x x x$ " refers to the mass numbers of the measured $\mathrm{Hg}$ isotopes: 199, 200, 201, 202, and 204. Mass independent fractionation (MIF) is reported as capital delta $\left(\Delta^{x x x} \mathrm{Hg}\right)$, which is defined as the deviation of the measured $\delta^{x x x} \mathrm{Hg}$ from those predicted from the measured $\delta^{202} \mathrm{Hg}$ value using the kinetic MDF law

$$
\Delta^{x x x} \mathrm{Hg}=\delta^{x x x} \mathrm{Hg}-\beta_{x x x} \times \delta^{202} \mathrm{Hg}
$$

where $\beta_{x x x}$ represents the scaling factor based on kinetic massdependent law of 0.252 for ${ }^{199} \mathrm{Hg}, 0.502$ for ${ }^{200} \mathrm{Hg}, 0.752$ for ${ }^{201} \mathrm{Hg}$, and 1.493 for ${ }^{204} \mathrm{Hg}$. ${ }^{65}$

The analytical precision was assessed by repeated measurements of two $\mathrm{Hg}$ standards over the course of 2 years, and the results agreed with previously published values. ${ }^{23,24,27}$ Results of the ETH-Fluka $\mathrm{Hg}$ standard are as follows: $\delta^{202} \mathrm{Hg}=-1.44$ $\pm 0.19 \%$ o $\Delta^{199} \mathrm{Hg}=0.08 \pm 0.1 \% \circ, \Delta^{200} \mathrm{Hg}=0.02 \pm 0.1 \%$, $\Delta^{201} \mathrm{Hg}=0.02 \pm 0.09 \%$, and $\Delta^{204} \mathrm{Hg}=-0.03 \pm 0.2 \%$ (mean $\pm 2 \sigma, n=73)$. Results for the UM-Almaden standard are as follows: $\delta^{202} \mathrm{Hg}=-0.58 \pm 0.15 \% \circ, \Delta^{199} \mathrm{Hg}=-0.02 \pm 0.09 \%$, $\Delta^{200} \mathrm{Hg}=0.00 \pm 0.1 \%$, $\Delta^{201} \mathrm{Hg}=-0.06 \pm 0.12 \%$, $\Delta^{204} \mathrm{Hg}=$ $-0.04 \pm 0.23 \%$ o (mean $\pm 2 \sigma, n=21)$. As standard reference material (SRM), marine sediment (MESS-3; Hg concentration, $91 \mathrm{ng} \mathrm{g}^{-1}$ ) was preconcentrated and measured together with the samples. Results for the MESS-3 SRM are as follows: $\delta^{202} \mathrm{Hg}=-1.87 \pm 0.14 \%$, $\Delta^{199} \mathrm{Hg}=0.01 \pm 0.04 \%$, $\Delta^{200} \mathrm{Hg}=$ $0.01 \pm 0.05 \%$ o, $\Delta^{201} \mathrm{Hg}=-0.03 \pm 0.03 \%$, $\Delta^{204} \mathrm{Hg}=0.01 \pm$ $0.10 \%$ (mean $\pm 2 \sigma, n=4$ ) and agreed with previously published values. ${ }^{13,66,67}$

2.5. Mixing Model for Source and Process Tracing. The source of $\mathrm{Hg}$ in sediment samples was estimated using a sequential mixing model to derive first the source fraction of geological $\mathrm{Hg}$ from bedrock based on $\mathrm{Hg} / \mathrm{Ti}$ elemental ratios and, second, the source fraction of atmospheric $\mathrm{Hg}$ (II) and $\mathrm{Hg}(0)$ deposition based on $\Delta^{200} \mathrm{Hg}$. The fraction of geological $\mathrm{Hg}$ from bedrock $\left(f_{\text {goeg }}\right)$ was calculated from the $\mathrm{Hg} / \mathrm{Ti}$ ratio measured in the sediment sample $\left(\mathrm{Hg} / \mathrm{Ti}_{\text {sediment }}\right)$ relative to the $\mathrm{Hg} / \mathrm{Ti}$ ratio in the bedrock of the catchment area, which was approximated by soil samples taken from the Katari subcatchment as follows

$$
f_{\text {geog }}=\frac{\mathrm{Hg}}{\mathrm{Ti}_{\text {soil }}} / \frac{\mathrm{Hg}}{\mathrm{Ti}_{\text {sediment }}}
$$

The excess $\mathrm{Hg}$, which was not derived from geogenic $\mathrm{Hg}$, was attributed to atmospheric $\mathrm{Hg}$ deposition to the lake. We assumed that geogenic $\mathrm{Hg}$ contained no even-MIF anomaly. ${ }^{68,69}$ The $\Delta^{200} \mathrm{Hg}$ observed in the sediment was therefore attributed to the net atmospheric $\mathrm{Hg}$ deposition component in the sediment

$$
\Delta^{200} \mathrm{Hg}_{\text {Atmos }}=\Delta^{200} \mathrm{Hg}_{\text {sed }} /\left(1-f_{\text {geog }}\right)
$$

We assume that even-MIF anomalies were exclusively produced during upper atmospheric redox transformations and that postdeposition processes (i.e., photoreduction in the watershed or the lake) did not fractionate $\Delta^{200} \mathrm{Hg}$ values. ${ }^{24,70}$ We then used a binary isotope mixing model to calculate the relative contributions of atmospheric $\mathrm{Hg}$ (II) dry and wet deposition and $\operatorname{Hg}(0)$ deposition to the lake sediments based on the calculated $\Delta^{200} \mathrm{Hg}$ values of the atmospheric $\mathrm{Hg}$ contribution $\left(\Delta^{200} \mathrm{Hg}_{\text {Atmos }}\right.$, eq 4$)$

$$
\begin{aligned}
\Delta^{200} \mathrm{Hg}_{\text {Atmos }}= & f_{\mathrm{Hg}(\mathrm{II})} \times \Delta^{200} \mathrm{Hg}_{\mathrm{Hg}(\mathrm{II})}+f_{\mathrm{Hg}(0)} \\
& \times \Delta^{200} \mathrm{Hg}_{\mathrm{Hg}(0)}
\end{aligned}
$$

where $f_{\mathrm{Hg}(\mathrm{II})}$ and $f_{\mathrm{Hg}(0)}$ represent the fractions of atmospheric $\mathrm{Hg}(\mathrm{II})$ and $\mathrm{Hg}(0)$ deposition preserved in the sediments, respectively, and $\Delta^{200} \mathrm{Hg}_{\mathrm{Hg}(\mathrm{II})}$ and $\Delta^{200} \mathrm{Hg}_{\mathrm{Hg}(0)}$ are the isotopic compositions of the atmospheric end-members according to literature values. The theoretical $\Delta^{199} \mathrm{Hg}$ in the sediment expected from conservative source mixing $\left(\Delta^{199} \mathrm{Hg}_{\text {sources }}\right)$ in the absence of odd-MIF isotope fractionation after deposition was calculated as follows

$$
\begin{aligned}
\Delta^{199} \mathrm{Hg}_{\text {sources }}= & f_{\mathrm{Hg}(\mathrm{II})} \times \Delta^{199} \mathrm{Hg}_{\mathrm{Hg}(\mathrm{II})}+f_{\mathrm{Hg}(0)} \\
& +\Delta^{199} \mathrm{Hg}_{\mathrm{Hg}(0)}+f_{\text {geog }} \times \Delta^{199} \mathrm{Hg}_{\text {geog }}
\end{aligned}
$$

The isotope signatures of atmospheric sources, $\Delta^{199} \mathrm{Hg}_{\mathrm{Hg}(\mathrm{II})}$ and $\Delta^{199} \mathrm{Hg}_{\mathrm{Hg}(0)}$, were derived from literature values. The excess $\Delta^{199} \mathrm{Hg}$ in a sample $\left(\Delta^{199} \mathrm{Hg}_{\text {exc }}\right)$, representing the oddMIF that could not be explained by the conservative mixing of the sources, was calculated by the difference between the sediment $\left(\Delta^{199} \mathrm{Hg}_{\text {sed }}\right)$ and $\Delta^{199} \mathrm{Hg}_{\text {sources }}$ calculated from eq 6

$$
\Delta^{199} \mathrm{Hg}_{\text {exc }}=\Delta^{199} \mathrm{Hg}_{\text {sed }}-\Delta^{199} \mathrm{Hg}_{\text {sources }}
$$

Despite the common assumption that $\Delta^{200} \mathrm{Hg}$ is not fractionated during in-lake processes, the preferential reduction of rainfall $\mathrm{Hg}$ over watershed $\mathrm{Hg}$ may affect the final $\Delta^{200} \mathrm{Hg}$ registered in sediments. We therefore stress that the sediment $\Delta^{200} \mathrm{Hg}$ mass balance reflects the net contributions of the endmembers to sediment and not the gross contributions to the lake. The uncertainty in the mixing models originating from the variation of the source end-members was simulated using a Monte Carlo-based approach using the random number generation function rnorm of $\mathrm{R}$ assuming that endmember data are normally distributed. ${ }^{25,27}$

2.6. Inorganic Geochemistry and Organic Biomarkers. The methodological details for the determination of trace and major element concentrations, organic carbon content, and organic biomarkers are given in a previous publication. ${ }^{60}$ Briefly, trace and major element concentrations were determined by acid digestion $\left(\mathrm{HNO}_{3} / \mathrm{H}_{2} \mathrm{O}_{2} / \mathrm{HF}\right)$ and inductively coupled plasma atomic emission spectroscopy (Varian ICP-AES 720ES, for major elements) or inductively coupled plasma mass spectrometry (Agilent ICP-MS $7500 \mathrm{CE}$, for trace elements) at ISTerre (OSUG-France). The total carbon content (TC, \%), organic carbon content $\left(C_{\text {org }} \%\right)$, and their isotopic composition $\left(\delta^{13} \mathrm{C}\right.$ and $\left.\delta^{13} \mathrm{Corg}, \% o\right)$ were measured by a Cavity Ring-Down Spectrometer (Picarro, Inc.) 


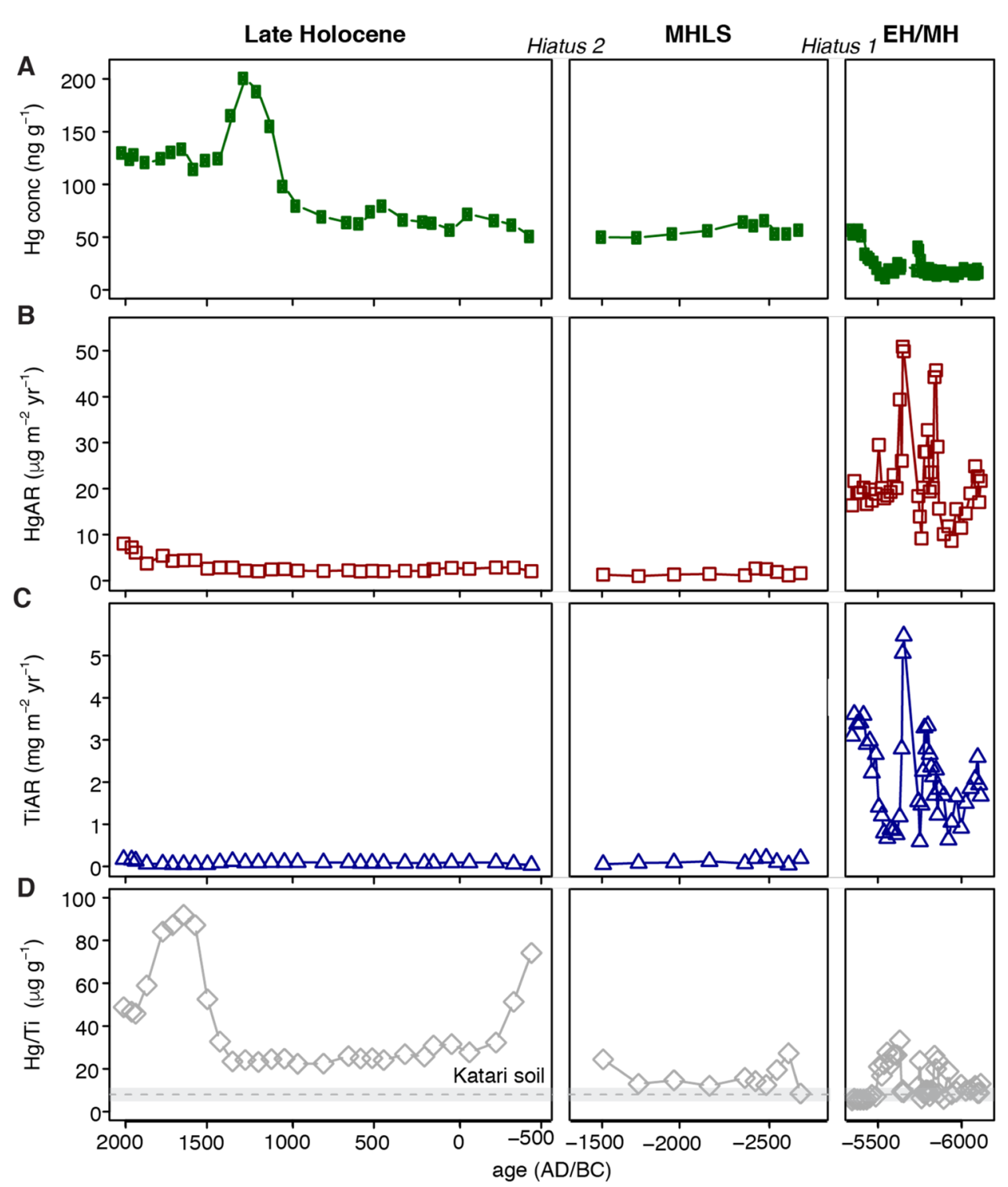

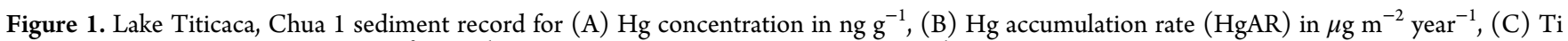
accumulation rate (TiAR) in $\mathrm{mg} \mathrm{m}^{-2} \mathrm{year}^{-1}$, and (D) $\mathrm{Hg} / \mathrm{Ti}$ element ratio in $\mu \mathrm{g} \mathrm{g}^{-1}$ as source tracer for detrital input of geogenic $\mathrm{Hg}$. The terrestrial source region is characterized by the gray dashed line representing the mean and the shaded area the range of $\mathrm{Hg} / \mathrm{Ti}$ values in surface soils of the Katari catchment $(n=3)$.

coupled with a Combustion Module (CM-CRDS, Costech, Inc.). Organic biomarkers and organic carbon-to-nitrogen (C/ $\mathrm{N})$ ratios were determined using pyrolysis-gas chromatography/mass spectrometry (Py-GC/MS; a Frontier Labs PY$2020 \mathrm{iD}$ oven connected to an Agilent 7890A-5975C GC/MS) (Supporting Information).

\section{RESULTS AND DISCUSSION}

The age-depth model for the study sediment core (Chua 1) and a detailed description of the sedimentary inorganic geochemistry, trace element (e.g., $\mathrm{Cu}, \mathrm{Hg}, \mathrm{Pb}$ ) accumulation rates, and organic biomarkers are presented in Guédron et al. ${ }^{60}$ The different climatic, ecological, and anthropogenic periods reconstructed from Chua 1 are summarized in the Supporting Information. The varved Chua 1 core was interrupted by hiatus 1 between approximately 5300 and 2900 BC and hiatus 2 between approximately 1300 and $500 \mathrm{BC}$, during which time the lake water level was very low. The Chua 1 archive thus represents three periods separated by the two hiatuses, the early to mid-Holocene (EH/MH, 6129-5340 BC), the Middle Holocene Low Stand (MHLS, 2687-1359 BC), and the late Holocene (LH, $428 \mathrm{BC}$ to present).

3.1. Hg Accumulation Rates and Geogenic $\mathrm{Hg}$ Sources. $\mathrm{Hg}$ concentrations were lower in the $\mathrm{EH} / \mathrm{MH}$ $\left(20.7 \pm 7.8 \mathrm{ng} \mathrm{g}^{-1}\right)$ and MHLS $\left(21.7 \pm 7.4 \mathrm{ng} \mathrm{g}^{-1}\right)$ and increased in the last 2000 years to a peak concentration of 200 $\mathrm{ng} \mathrm{g}^{-1}$ around $\mathrm{AD} 1700$ during Spanish colonization (Figure 1A). After the peak in the 18 th century, $\mathrm{Hg}$ concentrations decreased again to relatively stable levels around $125 \mathrm{ng} \mathrm{g}^{-1}$ until present. The $\mathrm{Hg}$ accumulation rate (HgAR) represents the net $\mathrm{Hg}$ deposition rate in the sediment and corrects for bulk sedimentation rates and density (Figure S2). Uncertainties in $\mathrm{HgAR}$ are dependent on $\mathrm{Hg}$ measurement uncertainty $(<5 \%)$, density measurements $(<5 \%)$, and age dating and are on average approximately $10 \%$ for this study. The highest HgARs in the Chua 1 record are found during the $\mathrm{EH} / \mathrm{MH}$ $\left(20.2 \pm 6.9 \mu \mathrm{g} \mathrm{m}^{-2}\right.$ year $\left.^{-1}\right)$ and exceed the modern HgARs by 


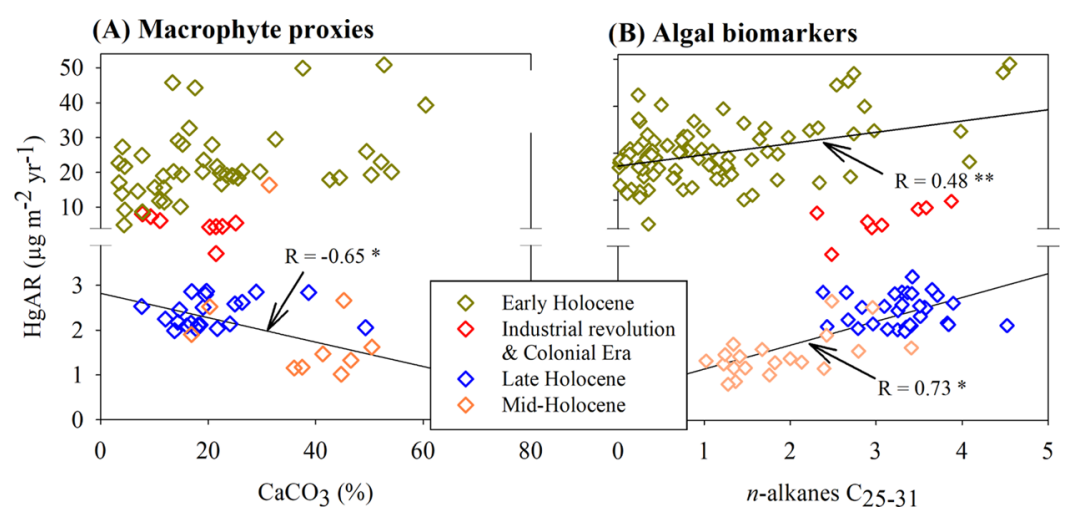

Figure 2. Correlations between $\mathrm{HgARs}$ and $(\mathrm{A}) \mathrm{CaCO}_{3}$ concentrations, a proxy for macrophytes, and (B) abundances of $\mathrm{n}$-alkanes $\mathrm{C}_{25-31}$, a proxy for algae. Regressions marked with ** are for the early Holocene $(\mathrm{EH}, \sim 6500$ to $5300 \mathrm{BC})$ and marked with * are for the mid- and late Holocene (AD 1450-1820).

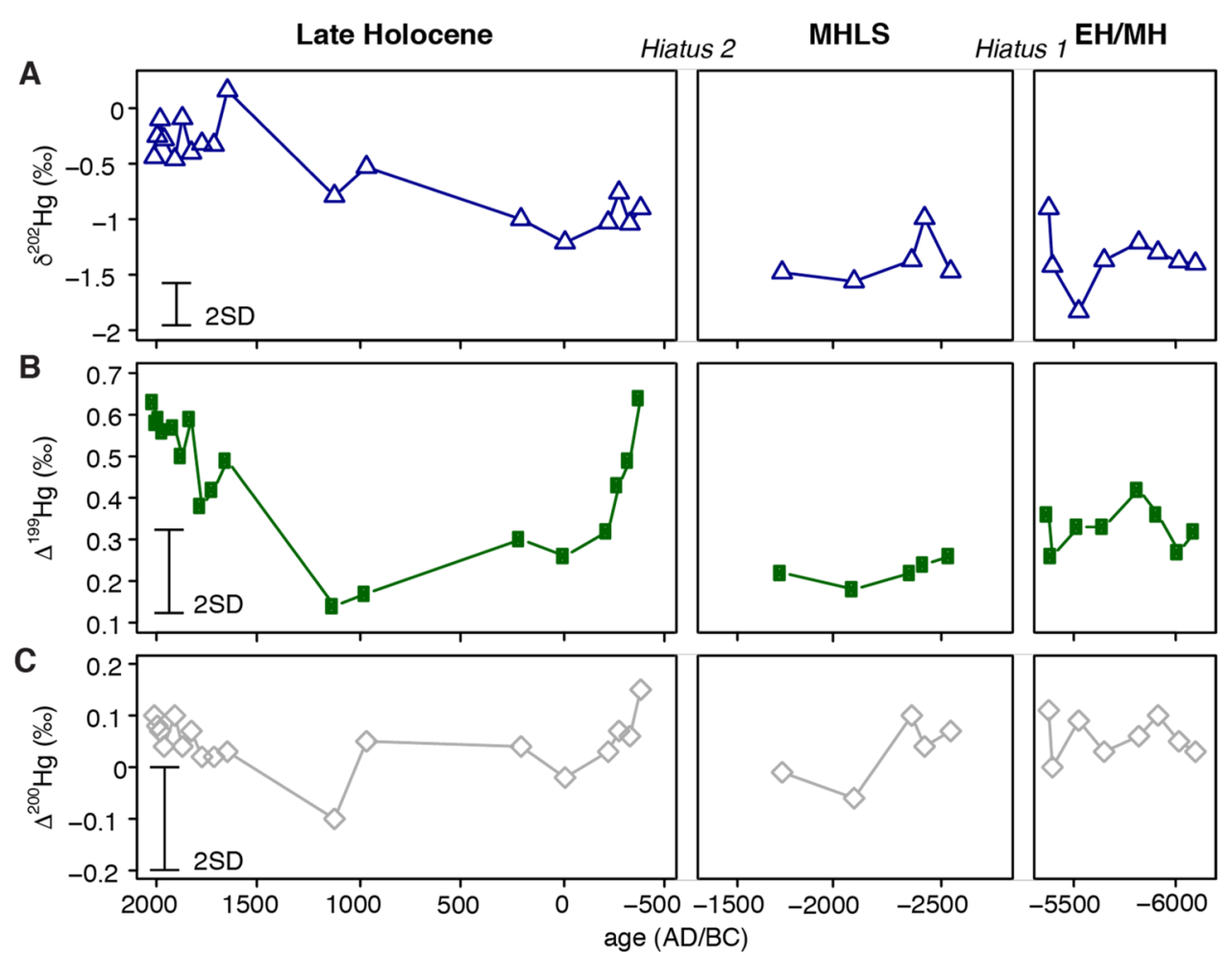

Figure 3. Mercury stable isotope record of Lake Titicaca, Chua 1 sediment core. (A) Mass-dependent $\mathrm{Hg}$ stable isotope signatures as $\delta^{202} \mathrm{Hg}$, (B) odd-mass-independent $\mathrm{Hg}$ stable isotope signature as $\Delta^{199} \mathrm{Hg}$, and $(\mathrm{C})$ even-mass-independent $\mathrm{Hg}$ stable isotope signature as $\Delta^{200} \mathrm{Hg}$. The error bars represent 2 standard deviations (SD) of replicate in-house standard measurements.

a factor of $\sim 3$ (Figure $1 \mathrm{~B}$ ). In contrast, the lowest HgARs (1.5 $\pm 0.5 \mu \mathrm{g} \mathrm{m}^{-2}$ year $^{-1}$ ) were found at the end of the MHLS (ca. $2500-1500 \mathrm{BC}$ ). From $400 \mathrm{BC}$ to the modern period, the HgARs are 2-3 times higher than the HgARs of the first half of the $\mathrm{LH}$ (i.e., $500 \mathrm{BC}$ to $\mathrm{AD} 500 ; 2.5 \pm 0.4 \mu \mathrm{g} \mathrm{m}^{-2}$ year $^{-1}$ ), whereas the $\mathrm{Ti}$ accumulation rate $(\mathrm{TiAR})$ remained relatively constant over the LH (Figure 1C). This suggests a major anthropogenic $\mathrm{Hg}$ contribution to the sediment during the end of the Tiwanaku period ( $\mathrm{AD} 900-1150$; up to $2.6 \mu \mathrm{g} \mathrm{m}^{-2}$ year $^{-1}$ ), during the Inca and Colonial Era (AD 1400-1820; $\mathrm{HgAR}$ up to $5.2 \mu \mathrm{g} \mathrm{m}^{-2}$ year $^{-1}$ ), and a renewed increase of HgAR from the Industrial Era to the modern period (up to 9.8 $\mu \mathrm{g} \mathrm{m}^{-2}$ year $\left.^{-1}\right)$. The Chua $1 \mathrm{HgAR}$ record for the last 500 years bears similarities to other sediment $\mathrm{HgAR}$ profiles from Altiplano lakes of the western and central Altiplano, such as
Lake Chungará, ${ }^{14}$ Laguna Negrilla, ${ }^{13}$ and Laguna Lobato, ${ }^{71}$ which showed increases in HgAR during the Colonial Era Ag mining, followed by a second increase due to global industrial $\mathrm{Hg}$ release (i.e., from ca. $\mathrm{AD} 1850$ to present).

Chua 1 lake sediment $\mathrm{Hg}$ concentrations in the $\mathrm{EH} / \mathrm{MH}(20$ $\pm 5 \mathrm{ng} \mathrm{g}^{-1}$ ) are similar to $\mathrm{Hg}$ concentrations measured in Katari (Bolivia) river sediments $\left(22 \pm 19 \mathrm{ng} \mathrm{g}^{-1}, n=6\right)$ and surface soils $\left(18 \pm 12 \mathrm{ng} \mathrm{g}^{-1}, n=5\right)$ of the Katari subcatchment. The accumulation rate of $\mathrm{Ti}$ (TiAR) serves as a tracer for detrital material ${ }^{72}$ that reached the sediment core via soil erosion (Figure $1 \mathrm{C}$ ). It becomes apparent that both TiAR and HgAR (Figure 1B,C) were several-fold higher in the $\mathrm{EH} / \mathrm{MH}$ period than over the more recent 2700 year, indicating intense precipitation and the erosion of the watershed during the $\mathrm{EH} / \mathrm{MH}$. $\mathrm{Hg} / \mathrm{Ti}$ elemental ratios in 

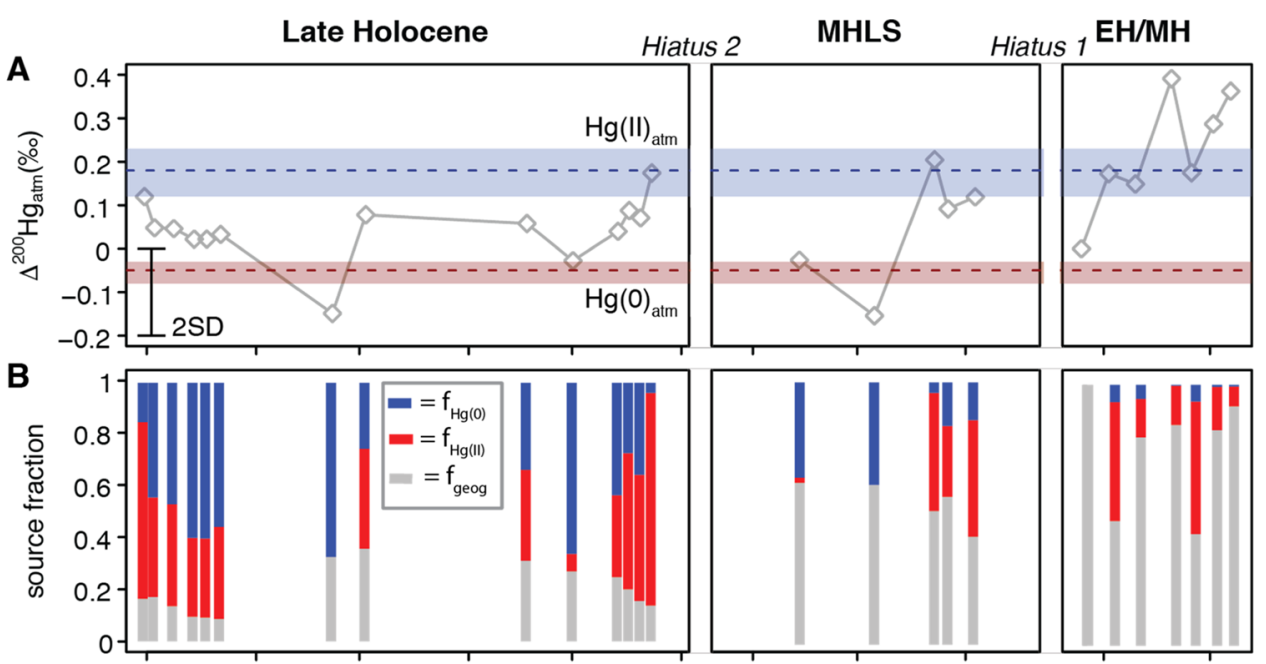

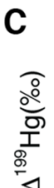

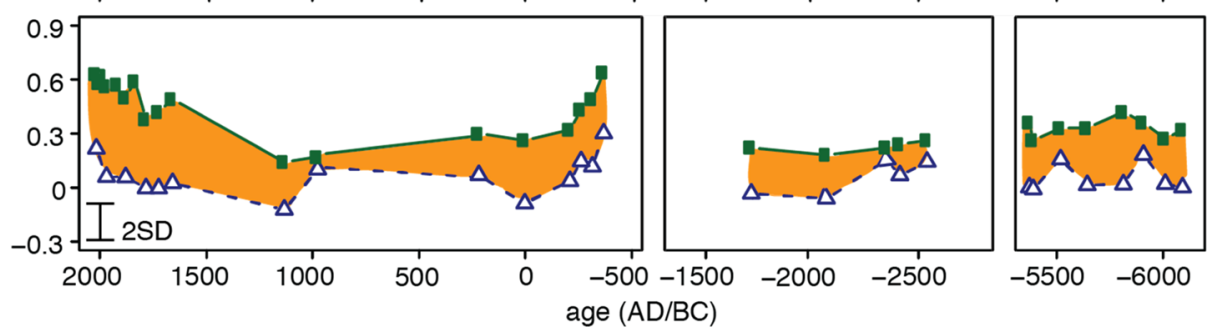

Figure 4. Sources of $\mathrm{Hg}$ to Lake Titicaca. (A) Atmospheric $\mathrm{Hg}$ deposition source tracing. Odd-MIF isotope signature of atmospheric $\mathrm{Hg}$ deposition $\left(\Delta^{200} \mathrm{Hg}_{\text {atm }}\right)$ corrected for the geogenic contribution to the sediment. The atmospheric sources are indicated by the blue dashed line representing the median of modern $\mathrm{NH} \mathrm{Hg}$ (II) wet deposition $\left(\mathrm{Hg}(\mathrm{II})_{\text {atm }}\right)$, and the red dashed line represents the median of modern atmospheric $\mathrm{Hg}(0)\left(\mathrm{Hg}(0)_{\text {atm }}\right)$. The corresponding shaded areas represent the interquartile range (IQR). (B) Source fraction of geogenic (gray), atmospheric $\mathrm{Hg}$ (II) wet deposition (red), and direct dissolution of gaseous elemental $\mathrm{Hg}(0)$ (blue). (C) Tracing in-lake photoreduction. The green squares represent the observed $\Delta^{199} \mathrm{Hg}$ in the sediment, and the blue triangles represent the $\Delta^{199} \mathrm{Hg}$ expected from conservative mixing of the sources derived from $\Delta^{200} \mathrm{Hg}$. The orange shaded area represents the excess odd-mass anomaly $\left(\Delta^{199} \mathrm{Hg}_{\text {exc }}\right.$ eq 7$)$ not explainable by source mixing.

soil profiles from the Katari subcatchment were relatively constant with a mean of $8.0 \mathrm{ng} \mathrm{mg}^{-1}\left(3.9-10.9 \mathrm{ng} \mathrm{mg}^{-1}\right.$, min to max, Figure $1 \mathrm{D})$. We used $\mathrm{Hg} / \mathrm{Ti}$ ratios measured in the sediment to calculate the contribution of geogenic $\mathrm{Hg}$ to sediments via soil erosion (eq 3). Geogenic $\mathrm{Hg}$ contributed on average $79 \%$ (interquartile range (IQR), 64-89\%) during the $\mathrm{EH} / \mathrm{MH}, 54 \%$ (IQR, 40-69\%) during the MHLS, and $20 \%$ (IQR, 14-25\%) during the $\mathrm{LH}$ to the total sediment $\mathrm{Hg}$ input. In absolute terms, sediment $\mathrm{Hg}$ accumulation rates from bedrock erosion $\left(\mathrm{HgAR}_{\text {geol }}\right)$ were on average $16.7 \mu \mathrm{g} \mathrm{m}^{-2}$ year $^{-1}$ (IQR, 13.5-18.9 $\mu \mathrm{g} \mathrm{m}^{-2}$ year $^{-1}$ ) during the $\mathrm{EH} / \mathrm{MH}$, $0.91 \mu \mathrm{g} \mathrm{m}^{-2}$ year $^{-1}$ (IQR, 0.67-1.15 $\mu \mathrm{g} \mathrm{m}^{-2}$ year $^{-1}$ ) during the MHLS, and $0.67 \mu \mathrm{g} \mathrm{m}^{-2}$ year $^{-1}$ (IQR, 0.49-0.84 $\mu \mathrm{g} \mathrm{m}^{-2}$ year $^{-1}$ ) during the $\mathrm{LH}$.

A negative correlation was observed between HgARs and $\mathrm{CaCO}_{3}$, a proxy for dry conditions with high lake salinity leading to higher $\mathrm{CaCO}_{3}$ precipitation and Characeae productivity, for the $\mathrm{MH}$ to $\mathrm{LH}$ periods $(R=-0.65, p<$ 0.05; Figure 2A). This supports a decrease in HgARs due to lower $\mathrm{Hg}$ inputs by rain and in runoff during drier periods. In contrast, a positive correlation was found between HgARs and the abundance of $n$-alkanes $\mathrm{C}_{25-31}$, a biomarker for pelagic algae (e.g., Botryococcus braunii), ${ }^{73}$ for both the wet $\mathrm{EH}$ period $(R=0.48, p<0.05$; Figure $2 \mathrm{~B})$ and the $\mathrm{MH}$ to $\mathrm{LH}(R=0.73$, $p<0.01$; Figure $2 \mathrm{~B}$ ), with the exception of two outliers (i.e., the Colonial Era and the Industrial Revolution), which have elevated HgARs due to anthropogenic emissions. This supports the significant role of pelagic algae in scavenging inlake $\mathrm{Hg}$ and preserving it in sediment archives. ${ }^{74-76}$
3.2. Tracing Atmospheric Sources with $\Delta^{200} \mathrm{Hg}$. Chua 1 sediment was characterized by negative $\delta^{202} \mathrm{Hg}$ of $0.90 \%$ o $(-1.37$ to $-0.36 \%$ ) , median and interquartile range (IQR, $n=$ $33)$, positive $\Delta^{199} \mathrm{Hg}$ of $0.36 \%$ (0.26-0.54\%o, median and IQR), and $\Delta^{200} \mathrm{Hg}$ of $0.05 \%$ (0.03-0.09\%, median and IQR) (Figure 3). The isotopic variation represents varying $\mathrm{Hg}$ source inputs into the lake, as well as in-lake $\mathrm{Hg}$ transformations, e.g., $\Delta^{199} \mathrm{Hg}$ changes during in-lake photoreduction of $\mathrm{Hg}(\mathrm{II})$ to $\mathrm{Hg}(0){ }^{37,77}$ Postdeposition processes, however, are not believed to fractionate even-MIF $\left(\Delta^{200} \mathrm{Hg}\right)$ signatures according to current understanding, preserving the source signals of atmospheric $\mathrm{Hg}(0)$ and $\mathrm{Hg}$ (II) deposition pathways to earth surface reservoirs. ${ }^{6,24}$ In the case of lake sediments, $\mathrm{Hg}$ (II) contributions are from wet and dry deposition directly to the lake and to the catchment. Similarly, $\mathrm{Hg}(0)$ contributions result from foliar and soil uptake in the catchment and direct $\mathrm{Hg}(0)$ gas exchange between lake water and air. Once in the lake, $\mathrm{Hg}$ can be reduced and emitted to the atmosphere or settle to sediments as particulate $\mathrm{Hg}$. Finally, a fraction of sediment $\mathrm{Hg}$ can be reduced and diffused back to the water column. Lake sediment $\mathrm{Hg}$ therefore represents the integration of atmospheric $\mathrm{Hg}$ deposition to the lake surface and catchment runoff to the lake minus $\mathrm{Hg}$ reemission to the atmosphere following reduction.

$\mathrm{Hg}$ (II) in $\mathrm{NH}$ precipitation, excluding samples affected by anthropogenic pollution plumes $\left(>25 \mathrm{ng} \mathrm{L}^{-1}\right)$, is characterized by consistently positive $\Delta^{200} \mathrm{Hg}$ values (median, $0.18 \%$; $\mathrm{QR}$, $0.12-0.23 \% \circ ; n=126$, blue dashed line and blue area in Figure $4 \mathrm{~A}) .^{22-25,78-84}$ Gaseous oxidized $\mathrm{Hg}(\mathrm{II})$ forms in the 
atmosphere that can dry-deposit to water and land surfaces, and that are the precursor of rainfall $\mathrm{Hg}(\mathrm{II})$, were recently shown to also carry positive but slightly lower $\Delta^{200} \mathrm{Hg}$ values $(0.12 \pm 0.05 \% o) .{ }^{85}$ Our lack of inclusion of possible $\mathrm{Hg}$ (II) dry deposition in the mixing model might therefore be associated with a slight systematic underestimation of the $\mathrm{Hg}(\mathrm{II})$ endmember. In contrast, $\mathrm{NH}$ atmospheric $\mathrm{Hg}(0)$ exhibits consistent negative $\Delta^{200} \mathrm{Hg}$ values $(-0.05 \%$ o $(-0.08$ to $-0.02 \%$ ), median and IQR, $n=126$, red dashed line and red area in Figure 4A). In the absence of direct atmospheric isotope endmember observations on the Andean Altiplano, we extrapolate the $\mathrm{NH}$ observations of atmospheric $\mathrm{Hg}(\mathrm{II})$ deposition in precipitation and atmospheric $\mathrm{Hg}(0)$ to the Southern Hemisphere. The uniform distribution of $\mathrm{NH}$ $\Delta^{200} \mathrm{Hg}$ and $\Delta^{199} \mathrm{Hg}$ observations with latitude (Figure S3) supports the use of single values for atmospheric $\mathrm{Hg}$ endmembers in remote areas. However, it has recently been speculated that $\mathrm{Hg}$ (II) deposition in the $\mathrm{SH}$ may have lower $\Delta^{200} \mathrm{Hg}$ values than the $\mathrm{NH}$ because of a stronger influence of oceanic $\mathrm{Hg}$ in the $\mathrm{SH}^{86}$ The global variation of atmospheric $\mathrm{Hg}$ isotope signatures therefore needs to be assessed in future studies.

In the Chua 1 record, the even-MIF component of the atmospheric deposition $\left(\Delta^{200} \mathrm{Hg}_{\text {Atmos }}\right)$ was smaller than the end-members of $\mathrm{Hg}$ (II) wet deposition $(p<0.001$, one-sided $t$-test) and greater than atmospheric $\operatorname{Hg}(0)(p<0.001$, onesided $t$-test), suggesting that both atmospheric deposition pathways played a significant role in the last $8 \mathrm{k}$ years (Figure 4A). Using a binary mixing model (eq 5), we calculated an average contribution from atmospheric $\mathrm{Hg}$ (II) wet and dry deposition to the sediment of $19 \%$ (IQR, 10-29\%) during the $\mathrm{EH} / \mathrm{MH}, 24 \%$ (IQR: $18-31 \%$ ) during the MHLS, and 38\% (IQR: 29-49\%) during the LH. The contribution of atmospheric $\mathrm{Hg}(0)$ was insignificant for the $\mathrm{EH} / \mathrm{MH}, 22 \%$ (IQR, 7-42\%) during the MHLS, and 42\% (IQR, 26-56\%) during the LH. Chua 1 sediment $\Delta^{200} \mathrm{Hg}$ values are similar to the published values for freshwater sediments (i.e., $\Delta^{200} \mathrm{Hg}=$ $0.02 \pm 0.06 \%$; mean $\pm 1 \mathrm{SD}, n=306),{ }^{68}$ which receive on average $63 \%( \pm 28 \%, 1 \mathrm{SD})$ of $\mathrm{Hg}$ from $\mathrm{Hg}(0)$ predominantly taken up by watershed vegetation and transferred to the lake via catchment runoff. ${ }^{24}$

No significant relationship was found between $\Delta^{200} \mathrm{Hg}$ and lake water level, inorganic tracers, or organic biomarkers. The Lago Menor water level depends on Lago Mayor, where the cumulative difference between precipitation, runoff, and evaporation takes time to attain a new equilibrium. To account for this the lag time, we compared the $\Delta^{200} \mathrm{Hg}$ record of Chua 1 core to the $\delta^{18} \mathrm{O}$-derived precipitation record obtained from a ca. $6.6 \mathrm{k}$ year sediment record of the nearby Lake Umayo (i.e., $2500 \mathrm{BC}$ to $\mathrm{AD} 1800)^{55}$ combined with annual precipitation data from the Quelccaya ice record (AD 1820 to 1920$)^{87}$ and modern gauge data for the last century. ${ }^{88}$ We find a positive correlation between the $\Delta^{200} \mathrm{Hg}$ recorded in the sediment and the amount of precipitation $(R=0.74, p<0.01$, Figure 5). From $6500 \mathrm{BC}$ to $\mathrm{AD} 1500$, this correlation suggests that lake sediment $\Delta^{200} \mathrm{Hg}$ is, similarly to $\delta^{18} \mathrm{O}$, a proxy for changes in the intensity of the South American summer monsoon (SASM). We implicitly assume that changes in regional air mass provenance and $\mathrm{Hg}$ supply to Lake Titicaca are not accompanied by changes in $\mathrm{Hg}(\mathrm{II})$ and $\mathrm{Hg}(0)$ isotope endmembers, and this therefore requires additional study.

$\Delta^{200} \mathrm{Hg}$ and $\Delta^{199} \mathrm{Hg}$ in the Chua 1 record increased in the past 500 years, which could reflect an increase in precipitation

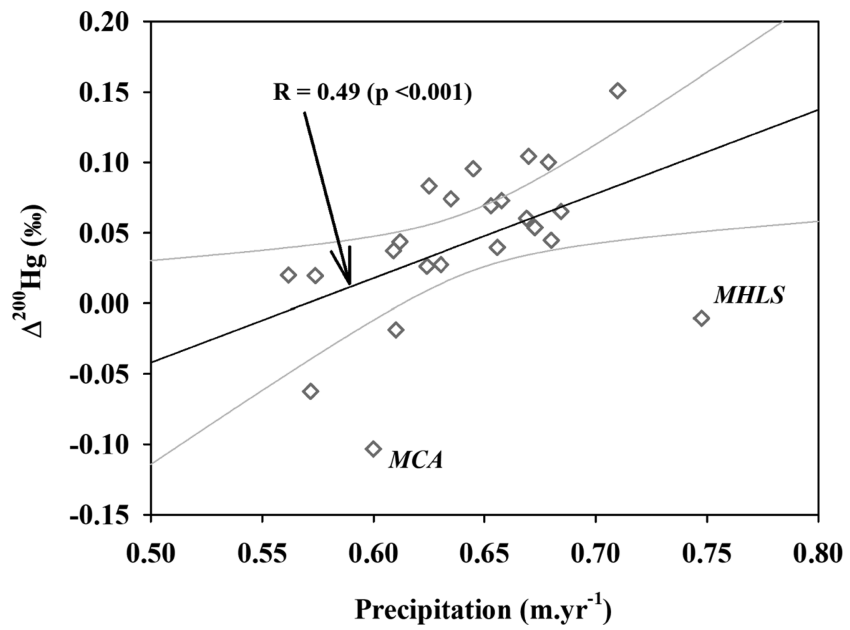

Figure 5. $\Delta^{200} \mathrm{Hg}$ recorded in the Chua 1 sediment core vs precipitation $\left(\mathrm{m} \mathrm{year}^{-1}\right)$. The black line represents the mean, and the gray curved lines represent the $95 \%$ confidence interval of the linear regression for the entire data set.

and/or increasing contribution of anthropogenic $\mathrm{Hg}$ emissions. The $\Delta^{200} \mathrm{Hg}$ value of Chua 1 increased linearly with time by $0.00018 \%$ o year ${ }^{-1}$ since $\mathrm{AD} 1500\left(R^{2}=0.51, p=0.02\right)$. Similarly, the Negrilla sediment core ${ }^{13}$ in the Peruvian Andes was associated with an increase of $\Delta^{200} \mathrm{Hg}$ in the last 500 years $\left(R^{2}=0.54, p=0.04\right)$, consistent with a regional prolonged intensification of the SASM with increased precipitation in the high tropical Andes between $\mathrm{AD} 1400$ and $18200^{89,90}$ In contrast, the El junco sediment core, ${ }^{13}$ situated on Galapagos island and influenced by marine climate and the absence of local anthropogenic $\mathrm{Hg}$ sources, exhibited no significant trend of $\Delta^{200} \mathrm{Hg}$ over the same period $(p=0.65)$. For remote sediment cores in North America, similar increases of $0.00014 \%$ o year ${ }^{-1}$ since 1820 were interpreted as a temporal change in global atmospheric $\mathrm{Hg}$ isotope composition due to anthropogenic emissions. ${ }^{41}$ At the same time, the United States has experienced a $10 \%$ increase in precipitation in the 20th century. ${ }^{91}$ Emission inventories suggested that anthropogenic $\mathrm{Hg}$ emissions since $\mathrm{AD} 1850$ exhibited relatively constant circum-zero $\Delta^{199} \mathrm{Hg}$ and $\Delta^{200} \mathrm{Hg}$ signatures over time. ${ }^{92}$ A global analysis also found that most lake sediments were associated with small or insignificant temporal increases in $\Delta^{200} \mathrm{Hg}$ since $1850{ }^{8}$ We therefore suggest that the endmember $\Delta^{200} \mathrm{Hg}$ signature of global precipitation remained relatively constant over time and that the temporal variation of $\Delta^{200} \mathrm{Hg}$ in historical archives primarily reflects a variation in rainfall intensity and/or an increase in $\mathrm{Hg}$ (II) deposition flux from anthropogenic sources.

3.3. Tracing In-Lake Photoreduction with $\Delta^{199} \mathrm{Hg}$. We calculated the excess $\Delta^{199} \mathrm{Hg}_{\text {exc, }}$ the $\Delta^{199} \mathrm{Hg}$ value not explainable by source mixing, by correcting the observed $\Delta \Delta{ }^{199} \mathrm{Hg}$ for the source contribution of atmospheric $\mathrm{Hg}$ (II) and $\mathrm{Hg}(0)$ deposition using $\Delta^{200} \mathrm{Hg}$ values (eq 7) and assuming a uniform latitudinal distribution of $\Delta^{199} \mathrm{Hg}$ in $\mathrm{Hg}$ (II) wet deposition (Figure S3) and no $\Delta^{199} \mathrm{Hg}$ anomaly in bedrock material. ${ }^{68}$ Note that the calculated $\Delta^{199} \mathrm{Hg}_{\text {exc }}$ provides a lower-bound estimate as the source mixing model does not include a contribution of litterfall-derived $\mathrm{Hg}$ from the catchment, which is associated with a shift of approximately $-0.1 \%$ in $\Delta^{199} \mathrm{Hg}$ relative to atmospheric $\mathrm{Hg}(0){ }^{23,24}$ The observed Chua $1 \Delta^{199} \mathrm{Hg}$ values (Figure $4 \mathrm{C}$ 
straight line) were consistently more positive by $0.34 \%$ o (0.28-0.45\%o, median and IQR) compared to the expected $\Delta^{199} \mathrm{Hg}$ values from atmospheric and geological sources (Figure 4C, dashed line). $\Delta^{199} \mathrm{Hg}$ values in Chua 1 were also more positive than values in two sediment cores from the Peruvian Andes (Laguna Negrilla; median, $-0.05 \%$; IQR, -0.10 to $0.03 \%$ ) and the Galapagos Archipelago (El Junco lake; median, $-0.12 \%$; IQR, -0.18 to $0.00 \%$ ), despite similar $\Delta^{200} \mathrm{Hg}$ values. ${ }^{13}$ The $\mathrm{Hg}$ stable isotope record of a Laguna Negrilla sediment core also was characterized by an increase of $\Delta^{199} \mathrm{Hg}$ from circum-zero values during preindustrial times to a maximum of $0.3 \%$ during the 20 th century. ${ }^{13}$ Similar trends have been described recently for lake sediments in North America ${ }^{40,41}$ and the Tibetan plateau. ${ }^{39}$ The authors suggested that an increase in $\mathrm{Hg}$ photoreduction was caused by the higher levels of anthropogenically derived dissolved organic carbon (DOC) or lower periods of ice coverage. ${ }^{40}$

Under the assumption of circum-zero $\Delta^{200} \mathrm{Hg}$ in geogenic sources and an insignificant contribution of litterfall-derived $\mathrm{Hg}$, we suggest that the positive $\Delta^{199} \mathrm{Hg}_{\text {exc }}$ values were produced after deposition or discharge to Lake Titicaca, most likely during $\mathrm{Hg}$ (II) photoreduction in the water column. ${ }^{93}$ Experimental studies of photoreduction of $\mathrm{Hg}$ (II) to $\mathrm{Hg}(0)$ in the presence of natural organic matter (NOM) have demonstrated positive $\Delta^{199} \mathrm{Hg}$ anomalies in the residual $\mathrm{Hg}(\mathrm{II})$ fraction. ${ }^{37,77}$ This suggests that positive $\Delta^{199} \mathrm{Hg}$ anomalies are caused by substantial photochemical reduction of $\mathrm{Hg}(\mathrm{II})$ and subsequent re-emission losses of $\mathrm{Hg}(0)$. The slope of $\Delta^{199} \mathrm{Hg} / \Delta^{201} \mathrm{Hg}$ of all Chua 1 samples is $0.97 \pm 0.15$ (Figure S5) and thus within the experimentally observed range for photoreduction of $\mathrm{Hg}(\mathrm{II})$ to $\mathrm{Hg}(0) .{ }^{37}$ Few $\mathrm{Hg}$ stable isotope studies on $\mathrm{Hg}(\mathrm{II})$ reduction in surface waters exist. Demers et al. observed increasing odd-MIF $\Delta^{199} \mathrm{Hg}$ values along a river transect with decreasing dissolved $\mathrm{Hg}$ concentration. $^{94}$ Chen et al. observed large positive $\Delta^{199} \mathrm{Hg}$ values in boreal lakes and concluded that the anomalies were caused by photoreduction of $\mathrm{Hg}$ (II). ${ }^{95}$

Lake Titicaca $\Delta^{199} \mathrm{Hg}_{\text {exc }}$ gradually increases by $0.2 \%$ from the $\mathrm{EH}$ to $\mathrm{LH}$, with sporadic low values during MHLS and the Medieval Climate Anomaly (MCA) dry periods. The elevated $\Delta^{199} \mathrm{Hg}_{\text {exc }}$ in the last 350 years suggests that Lake Titicaca underwent increased loss of $\mathrm{Hg}(0)$ to the atmosphere following photoreduction of $\mathrm{Hg}$ (II). $\Delta^{199} \mathrm{Hg}_{\text {exc }}$ positively correlates with autochthonous $C_{\text {org }}$, produced by photosynthesis $(R=0.67, p<0.01)$, supporting the notion that $\Delta^{199} \mathrm{Hg}$ production during in-lake photoreduction may be controlled by DOC concentration, as proposed by Kurz et al. ${ }^{40}$

3.4. Mass-Dependent Fractionation during Hg Uptake and Incorporation in Sediments. $\delta^{202} \mathrm{Hg}$ in the Chua 1 sediment core increases from low values, $-1.5 \%$, in the $\mathrm{EH} /$ $\mathrm{MH}$ to higher values of $-1.0 \%$ around $\mathrm{AD} / \mathrm{BC}$ and finally to $-0.3 \%$ during the last 350 years. Sun et al. estimated $\delta^{202} \mathrm{Hg}$ of global primary anthropogenic $\mathrm{Hg}$ emissions to have increased from -1.2 to $-0.7 \%$, ${ }^{96}$ which could explain part of the temporal $\delta^{202} \mathrm{Hg}$ trend in Chua 1. Similar to $\Delta^{199} \mathrm{Hg}_{\mathrm{exc}}$, $\delta^{202} \mathrm{Hg}$ is positively correlated with $C_{\text {org }}(R=0.82, p<0.01)$ with organic $\mathrm{C} / \mathrm{N}$ values derived from Py-GC/MS data $(R=$ $0.77, p<0.01)$ and to a lesser extent to $n$-alkane $C_{25-31}(R=$ $0.56, p<0.05)$ for the entire record. This suggests that in-lake processes related to photochemistry and primary productivity may control part of the $\delta^{202} \mathrm{Hg}$ variability. Using $\Delta^{199} \mathrm{Hg}_{\text {exc }}$ values and the MDF fractionation factor reported for photochemical reduction of $\mathrm{Hg}(\mathrm{II})$ to $\mathrm{Hg}(0),{ }^{37}$ we estimate that $\delta^{202} \mathrm{Hg}$ in sediments may be enriched on average by $0.39 \%$ o $(0.26-0.50 \%$, IQR) relative to the source signature. Sorption of $\mathrm{Hg}$ (II) to particles on the other hand has been shown to result in lowering of $\delta^{202} \mathrm{Hg}$ values by -0.3 to $-0.6 \%$ in the sorbed phase, ${ }^{97,98}$ which may partly compensate for photochemical reduction. The $\delta^{202} \mathrm{Hg}$ value measured in the sediment of $-0.90 \%$ o $(-1.37$ to $-0.36 \%$, median and IQR) was higher than the $\delta^{202} \mathrm{Hg}$ reported for foliage $-2.8 \%$ o $(-3.0$ to $-2.3 \% 0)$ and organic soils $-1.81 \%$ ( -2.08 to $-1.47 \%$ ) and slightly higher than mineral soils $-1.6 \%$ $\left(-2.13\right.$ to $-1.21 \%$ ). ${ }^{99}$ The interpretation of $\delta^{202} \mathrm{Hg}$ as a source tracer is associated with large uncertainties due to different confounding fractionation processes discussed above. Acknowledging this uncertainty, the relatively high sediment $\delta^{202} \mathrm{Hg}$ provides support for direct deposition of atmospheric $\mathrm{Hg}(0)$ to the lake, rather than via vegetation uptake in the catchment area and transfer by erosion, for which lower $\delta^{202} \mathrm{Hg}$ would be expected. The absence of lignin oligomers by PyGC/MS, which is a highly specific proxy for higher plants, further supports a limited role for terrestrial carbon and thus $\mathrm{Hg}(0)$ taken up by foliage and transferred via runoff. Organic $\mathrm{C} / \mathrm{N}$ ratios of the sediment are also within the range of $\mathrm{C} / \mathrm{N}$ ratios of lacustrine algae measured in Lake Titicaca (Figure S6). ${ }^{45}$ Among organic proxies, only the low $\delta^{13} \mathrm{C}_{\text {org }}$ recorded during the $\mathrm{EH}$ suggests a possible contribution of eroded soil $\mathrm{OM}$ to the lake. We therefore suggest that the important atmospheric $\mathrm{Hg}(0)$ source inferred from $\Delta^{200} \mathrm{Hg}$ originates from direct $\mathrm{Hg}(0)$ uptake by lake water from the atmosphere. This suggests that for large lakes such as Titicaca, $\operatorname{Hg}(0)$ is an important direct source to lake water. This is consistent with a recent study finding that $50 \%$ of $\mathrm{Hg}$ in seawater is derived from direct uptake of atmospheric $\mathrm{Hg}(0) .^{70}$

During the last $\sim 500$ years of the record, the lake was overall fresh and deep, with fewer water level fluctuations than the previous period, ${ }^{58}$ facilitating the development of large expanses of totora sedges on the lake's shore. Totora sedges were reported to scavenge more than $90 \%$ of terrestrial eroded particles, ${ }^{100}$ preventing their sedimentation to deeper areas of the lake where the Chua 1 core was taken. Based on the absence of terrestrial biomarkers such as lignin, more positive $\delta^{202} \mathrm{Hg}$ values than terrestrial vegetation, ${ }^{99}$ and the positive correlation between the $\mathrm{HgAR}$ and algal biomarker abundance (n-alkane $\mathrm{C}_{25-31}$ ) (Figure $2 \mathrm{~B}$ ), we suggest that algae were the dominant $\mathrm{Hg}$ scavengers. The scavenging of surface lake water $\mathrm{Hg}$ by algae and its transfer to the sediment could explain the high proportion of atmospheric $\mathrm{Hg}(0)$-derived lake $\mathrm{Hg}(47 \pm$ $17 \%$ (mean $\pm 1 \mathrm{SD}$ ), $n=6$, Figure $4 \mathrm{~A}$ ) during the last 500 year and is in agreement with the literature on the importance of algae primary productivity in $\mathrm{Hg}$ transfer to sediments. ${ }^{74-76,101}$

In summary, Lake Titicaca is a sentinel of climate change in the southern tropical Andes and has experienced large fluctuations in lake level due to changes in precipitation regimes. We studied the effects of climate variations on $\mathrm{Hg}$ accumulation in sediments using $\mathrm{Hg}$ stable isotope signatures and other geochemical proxies. We observed that natural climate variations, in the form of pronounced wet and dry periods related to the South American summer monsoon (SAMS) dynamics, strongly affected HgARs in Lake Titicaca sediments during the Holocene. High HgARs, exceeding those of the 20th century, occurred during the early Holocene, where high rainfall caused a large transfer of geogenic $\mathrm{Hg}$ to the lake sediment by erosion. $\mathrm{Hg}$ stable isotopes revealed that direct lake water uptake of atmospheric gaseous $\mathrm{Hg}(0)$ is an 
important pathway during the MHLS and LH. We suggested that the increase in $\Delta^{200} \mathrm{Hg}$ in the sediment from $\mathrm{AD} 1500$ to present observed in Lake Titicaca is driven by an increase of precipitation intensity rather than a change in global atmospheric $\Delta^{200} \mathrm{Hg}$ endmember signature. These findings improve our understanding of climate controls on $\mathrm{Hg}$ stable isotope variation in sediment archives. Finally, $\mathrm{Hg}$ stable isotope fingerprinting may offer a new proxy for reconstructing paleoclimate history. In particular, the observed correlation between in situ produced odd-MIF $\left(\Delta^{199} \mathrm{Hg}_{\text {exc }}\right)$ with autochthonous $C_{\text {org }}$ and the positive correlation between $\Delta^{200} \mathrm{Hg}$ and rainfall are encouraging for further investigation on the ubiquity of these observations and their suitability as paleo proxies for in-lake photochemistry and precipitation, respectively.

\section{ASSOCIATED CONTENT}

\section{SI Supporting Information}

The Supporting Information is available free of charge at https://pubs.acs.org/doi/10.1021/acsearthspacechem.1c00304.

Table of measured $\mathrm{Hg}$ stable isotopes and calculated source fractions (XLSX)

Additional information and figures on biomarkers and $\mathrm{C} / \mathrm{N}$ ratios, chronology, and $\mathrm{Hg}$ stable isotopes (PDF)

\section{AUTHOR INFORMATION}

\section{Corresponding Authors}

Martin Jiskra - Géosciences Environnement Toulouse, UMR5563-IRD UR 234, Université Paul Sabatier, 31400 Toulouse, France; Environmental Geosciences, University of Basel, 4056 Basel, Switzerland; orcid.org/0000-00034991-8122; Email: martin.jiskra@unibas.ch

Stéphane Guédron - ISTerre, CNRS, IRD, IFSTTAR, Univ. Grenoble Alpes, Univ. Savoie Mont Blanc, 38000 Grenoble, France; (1) orcid.org/0000-0003-4229-1566;

Email: stephane.guedron@ird.fr

\section{Authors}

Julie Tolu - Department of Water Resources and Drinking Water, Eawag, 8600 Dübendorf, Switzerland; Institute of Biogeochemistry and Pollutant Dynamics, ETH Zurich, 8092 Zurich, Switzerland

Sherilyn C. Fritz - Department of Earth and Atmospheric Sciences, University of Nebraska-Lincoln, 68588 Lincoln, Nebraska, United States

Paul A. Baker - Division of Earth and Ocean Sciences, Duke University, 27708 Durham, North Carolina, United States

Jeroen E. Sonke - Géosciences Environnement Toulouse, UMR5563-IRD UR 234, Université Paul Sabatier, 31400

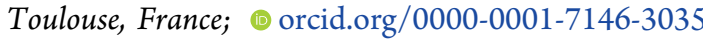

Complete contact information is available at: https://pubs.acs.org/10.1021/acsearthspacechem.1c00304

\section{Notes}

The authors declare no competing financial interest.

\section{ACKNOWLEDGMENTS}

This work is a contribution to the PaleoBol project (funded by IRD and ISTerre internal grants) and TRACISOMER (this work has been supported by a grant from Labex OSUG@2020 (Investissements d'avenir-ANR10 LABX56), PI: S.G., stephane.guedron@ird.fr). S.G. (ISTerre/IRD geochemistry team) is part of Labex OSUG@2020 (ANR10 LABX56). M.J. received funding from the European Union's Horizon 2020 Research and Innovation Programme under Marie Sklodowska-Curie grant agreement No. 657195 and the Swiss National Science Foundation Ambizione grant No. PZ00P2 174101. S.C.F. and P.A.B. received funding from the US NSF (EAR1338694) and from the National Geographic Society (929913). The authors thank J. Gardon, A. Terrazas, C. González, N. Clavijo, L. Salvatierra, R. Rios, J.C. Salinas, A. Castillo, M. Claure, J. Tapia, J.L. Duprey (IRD Bolivia), and la Familia Catari (Don Ramon, Don Maximo, Don Eric, Don Ruben, and Donia Maria) for their help and assistance during the field campaigns.

\section{REFERENCES}

(1) Lindberg, S.; Bullock, R.; Ebinghaus, R.; Engstrom, D.; Feng, X.; Fitzgerald, W.; Pirrone, N.; Prestbo, E.; Seigneur, C. A synthesis of progress and uncertainties in attributing the sources of mercury in deposition. Ambio 2007, 19-32.

(2) Pirrone, N.; Cinnirella, S.; Feng, X.; Finkelman, R. B.; Friedli, H. R.; Leaner, J.; Mason, R.; Mukherjee, A. B.; Stracher, G.; Streets, D. G.; Telmer, K. Global Mercury Emissions to the Atmosphere from Natural and Anthropogenic Sources. In Mercury Fate and Transport in the Global Atmosphere; Pirrone, N.; Mason, R., Eds.; Springer, 2010; Vol. 1, pp 3-50.

(3) Cooke, C. A.; Balcom, P. H.; Biester, H.; Wolfe, A. P. Over three millennia of mercury pollution in the Peruvian Andes. Proc. Natl. Acad. Sci. U.S.A. 2009, 106, 8830.

(4) Streets, D. G.; Horowitz, H. M.; Jacob, D. J.; Lu, Z.; Levin, L.; ter Schure, A. F. H.; Sunderland, E. M. Total Mercury Released to the Environment by Human Activities. Environ. Sci. Technol. 2017, 51, 5969-5977.

(5) Zhang, Y.; Jacob, D. J.; Horowitz, H. M.; Chen, L.; Amos, H. M.; Krabbenhoft, D. P.; Slemr, F.; St Louis, V. L.; Sunderland, E. M. Observed decrease in atmospheric mercury explained by global decline in anthropogenic emissions. Proc. Natl. Acad. Sci. U.S.A. 2016, $113,526-531$.

(6) Enrico, M.; Le Roux, G.; Heimburger, L. E.; Van Beek, P.; Souhaut, M.; Chmeleff, J.; Sonke, J. E. Holocene Atmospheric Mercury Levels Reconstructed from Peat Bog Mercury Stable Isotopes. Environ. Sci. Technol. 2017, 51, 5899-5906.

(7) Jiskra, M.; Sonke, J. E.; Obrist, D.; Bieser, J.; Ebinghaus, R.; Myhre, C. L.; Pfaffhuber, K. A.; Wangberg, I.; Kyllonen, K.; Worthy, D.; Martin, L. G.; Labuschagne, C.; Mkololo, T.; Ramonet, M.; Magand, O.; Dommergue, A. A vegetation control on seasonal variations in global atmospheric mercury concentrations. Nat. Geosci. 2018, 11, 244.

(8) Lee, J. H.; Kwon, S. Y.; Yin, R.; Motta, L. C.; Kurz, A. Y.; Nam, S.-I. Spatiotemporal Characterization of Mercury Isotope Baselines and Anthropogenic Influences in Lake Sediment Cores. Global Biogeochem. Cycles 2021, 35, No. e2020GB006904.

(9) Bindler, R. Estimating the natural background atmospheric deposition rate of mercury utilizing ombrotrophic bogs in southern Sweden. Environ. Sci. Technol. 2003, 37, 40-46.

(10) Rydberg, J.; Gälman, V.; Renberg, I.; Bindler, R.; Lambertsson, L.; Martinez-Cortizas, A. Assessing the stability of mercury and methylmercury in a varved lake sediment deposit. Environ. Sci. Technol. 2008, 42, 4391-4396.

(11) Li, C.; Sonke, J. E.; Le Roux, G.; Piotrowska, N.; Van der Putten, N.; Roberts, S. J.; Daley, T.; Rice, E.; Gehrels, R.; Enrico, M.; Mauquoy, D.; Roland, T. P.; De Vleeschouwer, F. Unequal Anthropogenic Enrichment of Mercury in Earth's Northern and Southern Hemispheres. ACS Earth Space Chem. 2020, 2073.

(12) Cooke, C. A.; Martínez-Cortizas, A.; Bindler, R.; Sexauer Gustin, M. Environmental archives of atmospheric $\mathrm{Hg}$ deposition - A review. Sci. Total Environ. 2020, 709, No. 134800. 
(13) Cooke, C. A.; Hintelmann, H.; Ague, J. J.; Burger, R.; Biester, H.; Sachs, J. P.; Engstrom, D. R. Use and Legacy of Mercury in the Andes. Environ. Sci. Technol. 2013, 47, 4181-4188.

(14) Guédron, S.; Tolu, J.; Brisset, E.; Sabatier, P.; Perrot, V.; Bouchet, S.; Develle, A. L.; Bindler, R.; Cossa, D.; Fritz, S. C.; Baker, P. A. Late Holocene volcanic and anthropogenic mercury deposition in the western Central Andes (Lake Chungará, Chile). Sci. Total Environ. 2019, 662, 903-914.

(15) Beal, S. A.; Jackson, B. P.; Kelly, M. A.; Stroup, J. S.; Landis, J. D. Effects of historical and modern mining on mercury deposition in Southeastern Peru. Environ. Sci. Technol. 2013, 47, 12715-12720.

(16) Biester, H.; Pérez-Rodriguez, M.; Gilfedder, B. S.; Martinez Cortizas, A.; Hermanns, Y. M. Solar irradiance and primary productivity controlled mercury accumulation in sediments of a remote lake in the Southern Hemisphere during the past 4000 years. Limnol. Oceanogr. 2018, 63, 540-549.

(17) Guédron, S.; Ledru, M. P.; Escobar-Torrez, K.; Develle, A. L.; Brisset, E. Enhanced mercury deposition by Amazonian orographic precipitation: Evidence from high-elevation Holocene records of the Lake Titicaca region (Bolivia). Palaeogeogr., Palaeoclimatol., Palaeoecol. 2018, 511, 577-587.

(18) Baker, P. A.; Fritz, S. C.; Garland, J.; Ekdahl, E. Holocene hydrologic variation at Lake Titicaca, Bolivia/Peru, and its relationship to North Atlantic climate variation. J. Quat. Sci. 2005, 20, 655662.

(19) Guédron, S.; Amouroux, D.; Sabatier, P.; Desplanque, C.; Develle, A.-L.; Barre, J.; Feng, C.; Guiter, F.; Arnaud, F.; Reyss, J. L.; Charlet, L. A hundred year record of industrial and urban development in French Alps combining $\mathrm{Hg}$ accumulation rates and isotope composition in sediment archives from Lake Luitel. Chem. Geol. 2016, 431, 10-19.

(20) Gratz, L. E.; Keeler, G. J.; Blum, J. D.; Sherman, L. S. Isotopic Composition and Fractionation of Mercury in Great Lakes Precipitation and Ambient Air. Environ. Sci. Technol. 2010, 44, 7764-7770.

(21) Chen, J.; Hintelmann, H.; Feng, X.; Dimock, B. Unusual fractionation of both odd and even mercury isotopes in precipitation from Peterborough, ON, Canada. Geochim. Cosmochim. Acta 2012, 90, 33-46.

(22) Sherman, L. S.; Blum, J. D.; Keeler, G. J.; Demers, J. D.; Dvonch, J. T. Investigation of local mercury deposition from a coalfired power plant using mercury isotopes. Environ. Sci. Technol. 2012, 46, 382-390.

(23) Demers, J. D.; Blum, J. D.; Zak, D. R. Mercury isotopes in a forested ecosystem: Implications for air-surface exchange dynamics and the global mercury cycle. Global Biogeochem. Cycles 2013, 27, $222-238$.

(24) Enrico, M.; Roux, G. L.; Marusczak, N.; Heimburger, L. E.; Claustres, A.; Fu, X.; Sun, R.; Sonke, J. E. Atmospheric mercury transfer to peat bogs dominated by gaseous elemental mercury dry deposition. Environ. Sci. Technol. 2016, 50, 2405-2412.

(25) Obrist, D.; Agnan, Y.; Jiskra, M.; Olson, C. L.; Colegrove, D. P.; Hueber, J.; Moore, C. W.; Sonke, J. E.; Helmig, D. Tundra uptake of atmospheric elemental mercury drives Arctic mercury pollution. Nature 2017, 547, 201-204.

(26) Guédron, S.; Amouroux, D.; Tessier, E.; Grimaldi, C.; Barre, J.; Berail, S.; Perrot, V.; Grimaldi, M. Mercury Isotopic Fractionation during Pedogenesis in a Tropical Forest Soil Catena (French Guiana): Deciphering the Impact of Historical Gold Mining. Environ. Sci. Technol. 2018, 52, 11573-11582.

(27) Jiskra, M.; Wiederhold, J. G.; Skyllberg, U.; Kronberg, R. M.; Hajdas, I.; Kretzschmar, R. Mercury deposition and re-emission pathways in boreal forest soils investigated with $\mathrm{Hg}$ isotope signatures. Environ. Sci. Technol. 2015, 49, 7188-7196.

(28) Zheng, W.; Obrist, D.; Weis, D.; Bergquist, B. A. Mercury isotope compositions across North American forests. Global Biogeochem. Cycles 2016, 30, 1475-1492.

(29) Wang, X.; Luo, J.; Yin, R.; Yuan, W.; Lin, C. J.; Sommar, J.; Feng, X.; Wang, H.; Lin, C. Using mercury isotopes to understand mercury accumulation in the montane forest floor of the Eastern Tibetan Plateau. Environ. Sci. Technol. 2017, 801.

(30) Jiskra, M.; Wiederhold, J. G.; Skyllberg, U.; Kronberg, R. M.; Kretzschmar, R. Source tracing of natural organic matter bound mercury in boreal forest runoff with mercury stable isotopes. Environ. Sci.: Processes Impacts 2017, 19, 1235-1248.

(31) Woerndle, G. E.; Tsz-Ki Tsui, M.; Sebestyen, S. D.; Blum, J. D.; Nie, X.; Kolka, R. K. New Insights on Ecosystem Mercury Cycling Revealed by Stable Isotopes of Mercury in Water Flowing from a Headwater Peatland Catchment. Environ. Sci. Technol. 2018, 52, $1854-1861$.

(32) Gleason, J. D.; Blum, J. D.; Moore, T. C.; Polyak, L.; Jakobsson, M.; Meyers, P. A.; Biswas, A. Sources and cycling of mercury in the paleo Arctic Ocean from $\mathrm{Hg}$ stable isotope variations in Eocene and Quaternary sediments. Geochim. Cosmochim. Acta 2017, 197, 245262.

(33) Lepak, R. F.; Yin, R.; Krabbenhoft, D. P.; Ogorek, J. M.; DeWild, J. F.; Holsen, T. M.; Hurley, J. P. Use of Stable Isotope Signatures to Determine Mercury Sources in the Great Lakes. Environ. Sci. Technol. Lett. 2015, 2, 335-341.

(34) Araujo, B. F.; Hintelmann, H.; Dimock, B.; Almeida, M. G.; Rezende, C. E. Concentrations and isotope ratios of mercury in sediments from shelf and continental slope at Campos Basin near Rio de Janeiro, Brazil. Chemosphere 2017, 178, 42-50.

(35) Grasby, S. E.; Shen, W.; Yin, R.; Gleason, J. D.; Blum, J. D.; Lepak, R. F.; Hurley, J. P.; Beauchamp, B. Isotopic signatures of mercury contamination in latest Permian oceans. Geology 2017, 45, $55-58$.

(36) Masbou, J.; Sonke, J. E.; Amouroux, D.; Guillou, G.; Becker, P. R.; Point, D. Hg-Stable Isotope Variations in Marine Top Predators of the Western Arctic Ocean. ACS Earth Space Chem. 2018, 2, 479-490.

(37) Bergquist, B. A.; Blum, J. D. Mass-dependent and -independent fractionation of $\mathrm{Hg}$ isotopes by photoreduction in aquatic systems. Science 2007, 318, 417-420.

(38) Zheng, W.; Hintelmann, H. Isotope fractionation of mercury during its photochemical reduction by low-molecular-weight organic compounds. J. Phys. Chem. A 2010, 114, 4246-4253.

(39) Yin, R.; Feng, X.; Hurley, J. P.; Krabbenhoft, D. P.; Lepak, R. F.; Kang, S.; Yang, H.; Li, X. Historical Records of Mercury Stable Isotopes in Sediments of Tibetan Lakes. Sci. Rep. 2016, 6, No. 23332.

(40) Kurz, A. Y.; Blum, J. D.; Washburn, S. J.; Baskaran, M. Changes in the mercury isotopic composition of sediments from a remote alpine lake in Wyoming, USA. Sci. Total Environ. 2019, 669, 973-982.

(41) Lepak, R. F.; Janssen, S. E.; Engstrom, D. R.; Krabbenhoft, D. P.; Tate, M. T.; Yin, R.; Fitzgerald, W. F.; Nagorski, S. A.; Hurley, J. P. Resolving Atmospheric Mercury Loading and Source Trends from Isotopic Records of Remote North American Lake Sediments. Environ. Sci. Technol. 2020, 54, 9325-9333.

(42) Abbott, M. B.; Binford, M. W.; Brenner, M.; Kelts, K. R. A 3500 14C yr High-Resolution Record of Water-Level Changes in Lake Titicaca, Bolivia/Peru. Quat. Res. 1997, 47, 169-180.

(43) Fritz, S. C.; Baker, P. A.; Seltzer, G. O.; Ballantyne, A.; Tapia, P.; Cheng, H.; Edwards, R. L. Quaternary glaciation and hydrologic variation in the South American tropics as reconstructed from the Lake Titicaca drilling project. Quat. Res. 2007, 68, 410-420.

(44) Dejoux, C. In Lake Titicaca: A Synthesis of Limnological Knowledge; Boston, Ed.; Kluwer Academic: Dordrecht (NLD), 1992; Vol. 68, p 579.

(45) Cross, S. L.; Baker, P. A.; Seltzer, G. O.; Fritz, S. C.; Dunbar, R. B. A new estimate of the Holocene lowstand level of Lake Titicaca, central Andes, and implications for tropical palaeohydrology. Holocene 2000, 10, 21-32.

(46) Aguilera, X.; Lazzaro, X.; Coronel, J. S. Tropical high-altitude Andean lakes located above the tree line attenuate UV-A radiation more strongly than typical temperate alpine lakes. Photochem. Photobiol. Sci. 2013, 12, 1649-1657.

(47) Helbling, E. W.; Villafañe, V.; Buma, A.; Andrade, M.; Zaratti, F. DNA damage and photosynthetic inhibition induced by solar 
ultraviolet radiation in tropical phytoplankton (Lake Titicaca, Bolivia). Eur. J. Phycol. 2001, 36, 157-166.

(48) Fritz, S. C.; Baker, P. A.; Lowenstein, T. K.; Seltzer, G. O.; Rigsby, C. A.; Dwyer, G. S.; Tapia, P. M.; Arnold, K. K.; Ku, T.-L.; Luo, S. Hydrologic variation during the last 170,000 years in the southern hemisphere tropics of South America. Quat. Res. 2004, 61, 95-104.

(49) Baker, P. A.; Rigsby, C. A.; Seltzer, G. O.; Fritz, S. C.; Lowenstein, T. K.; Bacher, N. P.; Veliz, C. Tropical climate changes at millennial and orbital timescales on the Bolivian Altiplano. Nature 2001, 409, 698-701.

(50) Baker, P. A.; Seltzer, G. O.; Fritz, S. C.; Dunbar, R. B.; Grove, M. J.; Tapia, P. M.; Cross, S. L.; Rowe, H. D.; Broda, J. P. The History of South American Tropical Precipitation for the Past 25,000 Years. Science 2001, 291, 640-643.

(51) Vuille, M. Atmospheric circulation over the Bolivian Altiplano during dry and wet periods and extreme phases of the Southern Oscillation. Int. J. Climatol. 1999, 1579.

(52) Chiessi, C. M.; Mulitza, S.; Pätzold, J.; Wefer, G.; Marengo, J. Possible impact of the Atlantic Multidecadal Oscillation on the South American summer monsoon. Geophys. Res. Lett. 2009, 36, No. L21707.

(53) Marengo, J. A. Interdecadal variability and trends of rainfall across the Amazon basin. Theor. Appl. Climatol. 2004, 78, 79-96.

(54) Zhou, J.; Lau, K. M. Principal modes of interannual and decadal variability of summer rainfall over South America. Int. J. Climatol. 2001, 21, 1623-1644.

(55) Baker, P. A.; Fritz, S. C.; Burns, S. J.; Ekdahl, E.; Rigsby, C. A. The Nature and Origin of Decadal to Millennial Scale Climate Variability in the Southern Tropics of South America: The Holocene record of Lago Umayo, Peru. Past Climate Variability in South America and Surrounding Regions; Springer, 2009; pp 301-322.

(56) Mourguiart, P.; Correge, T.; Wirrmann, D.; Argollo, J.; Montenegro, M. E.; Pourchet, M.; Carbonel, P. Holocene palaeohydrology of Lake Titicaca estimated from an ostracod-based transfer function. Palaeogeogr., Palaeoclimatol., Palaeoecol. 1998, 143, $51-72$.

(57) D’Agostino, K.; Seltzer, G.; Baker, P.; Fritz, S.; Dunbar, R. LateQuaternary lowstands of Lake Titicaca: evidence from high-resolution seismic data. Palaeogeogr., Palaeoclimatol., Palaeoecol. 2002, 179, 97111.

(58) Weide, D. M.; Fritz, S. C.; Hastorf, C. A.; Bruno, M. C.; Baker, P. A.; Guédron, S.; Salenbien, W. A 6000 yr diatom record of mid-to late Holocene fluctuations in the level of Lago Winaymarca, Lake Titicaca (Peru/Bolivia). Quat. Res. 2017, 88, 179-192.

(59) Jomelli, V.; Favier, V.; Rabatel, A.; Brunstein, D.; Hoffmann, G.; Francou, B. Fluctuations of glaciers in the tropical Andes over the last millennium and palaeoclimatic implications: A review. Palaeogeogr., Palaeoclimatol., Palaeoecol. 2009, 281, 269-282.

(60) Guédron, S.; Tolu, J.; Delaere, C.; Sabatier, P.; Barre, J.; Heredia, C.; Brisset, E.; Campillo, S.; Bindler, R.; Fritz, S. C.; Baker, P. A.; Amouroux, D. Reconstructing two millennia of copper and silver metallurgy in the Lake Titicaca region (Bolivia/Peru) using trace metals and lead isotopic composition. Anthropocene 2021, 34, No. 100288

(61) Guédron, S.; Grangeon, S.; Lanson, B.; Grimaldi, M. Mercury speciation in a tropical soil association; Consequence of gold mining on $\mathrm{Hg}$ distribution in French Guiana. Geoderma 2009, 153, 331-346.

(62) Roos-Barraclough, F.; Givelet, N.; Martinez-Cortizas, A.; Goodsite, M. E.; Biester, H.; Shotyk, W. An analytical protocol for determination of total mercury concentration in solid peat samples. Sci. Total Environ. 2002, 292, 129-139.

(63) Sun, R.; Heimbürger, L.-E.; Sonke, J. E.; Liu, G.; Amouroux, D.; Berail, S. Mercury stable isotope fractionation in six utility boilers of two large coal-fired power plants. Chem. Geol. 2013, 336, 103-111.

(64) Sun, R. Y.; Enrico, M.; Heimburger, L. E.; Scott, C.; Sonke, J. E. A double-stage tube furnace-acid-trapping protocol for the preconcentration of mercury from solid samples for isotopic analysis. Anal. Bioanal. Chem. 2013, 405, 6771-6781.
(65) Blum, J.; Bergquist, B. Reporting of variations in the natural isotopic composition of mercury. Anal. Bioanal. Chem. 2007, 388, 353-359.

(66) Donovan, P. M.; Blum, J. D.; Demers, J. D.; Gu, B.; Brooks, S. C.; Peryam, J. Identification of multiple mercury sources to stream sediments near Oak Ridge, TN, USA. Environ. Sci. Technol. 2014, 3666.

(67) Goix, S.; Maurice, L.; Laffont, L.; Rinaldo, R.; Lagane, C.; Chmeleff, J.; Menges, J.; Heimbürger, L.-E.; Maury-Brachet, R.; Sonke, J. E. Quantifying the impacts of artisanal gold mining on a tropical river system using mercury isotopes. Chemosphere 2019, 219, 684-694.

(68) Blum, J. D.; Sherman, L. S.; Johnson, M. W. Mercury Isotopes in Earth and Environmental Sciences. Annu. Rev. Earth Planet. Sci. 2014, 42, 249-269.

(69) Sun, R.; Jiskra, M.; Amos, H. M.; Zhang, Y.; Sunderland, E. M.; Sonke, J. E. Modelling the mercury stable isotope distribution of Earth surface reservoirs: Implications for global $\mathrm{Hg}$ cycling. Geochim. Cosmochim. Acta 2019, 246, 156-173.

(70) Jiskra, M.; Heimbürger-Boavida, L. E.; Desgranges, M. M.; Petrova, M. V.; Dufour, A.; Ferreira-Aruajo, B.; Masbou, J.; Chmeleff, J.; Thyssen, M.; Point, D.; Sonke, J. E. Mercury stable isotopes constrain atmospheric sources to the Ocean. Nature 2021, 678.

(71) Cooke, C. A.; Balcom, P. H.; Kerfoot, C.; Abbott, M. B.; Wolfe, A. P. Pre-Colombian mercury pollution associated with the smelting of argentiferous ores in the Bolivian Andes. Ambio 2011, 40, 18-25. (72) Cole, D. B.; Zhang, S.; Planavsky, N. J. A new estimate of detrital redox-sensitive metal concentrations and variability in fluxes to marine sediments. Geochim. Cosmochim. Acta 2017, 215, 337-353. (73) Theissen, K. M.; Zinniker, D. A.; Moldowan, J. M.; Dunbar, R. B.; Rowe, H. D. Pronounced occurrence of long-chain alkenones and dinosterol in a 25,000-year lipid molecular fossil record from Lake Titicaca, South America. Geochim. Cosmochim. Acta 2005, 69, 623636.

(74) Biester, H.; Pérez-Rodríguez, M.; Gilfedder, B.-S.; Martínez Cortizas, A.; Hermanns, Y.-M. Solar irradiance and primary productivity controlled mercury accumulation in sediments of a remote lake in the Southern Hemisphere during the past 4000 years. Limnol. Oceanogr. 2018, 63, 540-549.

(75) Outridge, P. M.; Sanei, L. H.; Stern, G. A.; Hamilton, P. B.; Goodarzi, F. Evidence for Control of Mercury Accumulation Rates in Canadian High Arctic Lake Sediments by Variations of Aquatic Primary Productivity. Environ. Sci. Technol. 2007, 41, 5259-5265.

(76) Outridge, P. M.; Stern, G. A.; Hamilton, P. B.; Sanei, H. Algal scavenging of mercury in preindustrial Arctic lakes. Limnol. Oceanogr. 2019, 64, 1558-1571.

(77) Rose, C. H.; Ghosh, S.; Blum, J. D.; Bergquist, B. A. Effects of ultraviolet radiation on mercury isotope fractionation during photoreduction for inorganic and organic mercury species. Chem. Geol. 2015, 405, 102-111.

(78) Sherman, L. S.; Blum, J. D.; Dvonch, J. T.; Gratz, L. E.; Landis, M. S. The use of $\mathrm{Pb}, \mathrm{Sr}$, and $\mathrm{Hg}$ isotopes in Great Lakes precipitation as a tool for pollution source attribution. Sci. Total Environ. 2015, 502, $362-374$.

(79) Gratz, L. E.; Keeler, G. J.; Blum, J. D.; Sherman, L. S. Isotopic composition and fractionation of mercury in great lakes precipitation and ambient air. Environ. Sci. Technol. 2010, 44, 7764-7770.

(80) Wang, Z.; Chen, J.; Feng, X.; Hintelmann, H.; Yuan, S.; Cai, H.; Huang, Q.; Wang, S.; Wang, F. Mass-dependent and massindependent fractionation of mercury isotopes in precipitation from Guiyang, SW China. C. R. Geosci. 2015, 347, 358-367.

(81) Motta, L. C.; Blum, J. D.; Johnson, M. W.; Umhau, B. P.; Popp, B. N.; Washburn, S. J.; Drazen, J. C.; Benitez-Nelson, C. R.; Hannides, C. C. S.; Close, H. G.; Lamborg, C. H. Mercury cycling in the North Pacific Subtropical Gyre as revealed by mercury stable isotope ratios. Global Biogeochem. Cycles 2019, 777.

(82) Donovan, P. M.; Blum, J. D.; Yee, D.; Gehrke, G. E.; Singer, M. B. An isotopic record of mercury in San Francisco bay sediment. Chem. Geol. 2013, 349-350, 87-98. 
(83) Huang, S.; Sun, L.; Zhou, T.; Yuan, D.; Du, B.; Sun, X. Natural stable isotopic compositions of mercury in aerosols and wet precipitations around a coal-fired power plant in Xiamen, southeast China. Atmos. Environ. 2018, 173, 72-80.

(84) Wang, X.; Luo, J.; Yuan, W.; Lin, C.-J.; Wang, F.; Liu, C.; Wang, G.; Feng, X. Global warming accelerates uptake of atmospheric mercury in regions experiencing glacier retreat. Proc. Natl. Acad. Sci. U.S.A. 2020, 2049.

(85) Fu, X.; Jiskra, M.; Yang, X.; Marusczak, N.; Enrico, M.; Chmeleff, J.; Heimburger-Boavida, L. E.; Gheusi, F.; Sonke, J. E. Mass-Independent Fractionation of Even and Odd Mercury Isotopes during Atmospheric Mercury Redox Reactions. Environ. Sci. Technol. 2021, 55, 10164-10174.

(86) Blum, J. D.; Drazen, J. C.; Johnson, M. W.; Popp, B. N.; Motta, L. C.; Jamieson, A. J. Mercury isotopes identify near-surface marine mercury in deep-sea trench biota. Proc. Natl. Acad. Sci. U.S.A. 2020, 117, 29292-29298.

(87) Thompson, L. G.; Davis, M. E.; Mosley-Thompson, E.; Liu, K. B. Pre-Incan agricultural activity recorded in dust layers in two tropical ice cores. Nature 1988, 336, 763-765.

(88) SENAMHI, B., Servicio Nacional de Meteorología de Hidrologia. La Paz, Bolivia, 2020. http://www.senamhi.gob.bo.

(89) Bird, B. W.; Abbott, M. B.; Vuille, M.; Rodbell, D. T.; Stansell, N. D.; Rosenmeier, M. F. A 2,300-year-long annually resolved record of the South American summer monsoon from the Peruvian Andes. Proc. Natl. Acad. Sci. U.S.A. 2011, 108, 8583.

(90) Thompson, L. G.; Mosley-Thompson, E.; Davis, M. E.; Zagorodnov, V. S.; Howat, I. M.; Mikhalenko, V. N.; Lin, P.-N. Annually Resolved Ice Core Records of Tropical Climate Variability over the Past $\sim 1800$ Years. Science 2013, 340, 945-950.

(91) Karl, T. R.; Knight, R. W. Secular Trends of Precipitation Amount, Frequency, and Intensity in the United States. Bull. Am. Meteorol. Soc. 1998, 79, 231-242.

(92) Sun, R.; Streets, D. G.; Horowitz, H. M.; Amos, H. M.; Liu, G.; Perrot, V.; Toutain, J.-P.; Hintelmann, H.; Sunderland, E. M.; Sonke, J. E. Historical (1850-2010) mercury stable isotope inventory from anthropogenic sources to the atmosphere. Elementa: Sci. Anthropocene 2016, 4, No. 000091

(93) Guédron, S.; Achá, D.; Bouchet, S.; Point, D.; Tessier, E.; Heredia, C.; Rocha-Lupa, S.; Fernandez-Saavedra, P.; Flores, M.; Bureau, S.; et al. Accumulation of Methylmercury in the HighAltitude Lake Uru Uru (3686 m asl, Bolivia) Controlled by Sediment Efflux and Photodegradation. Appl. Sci. 2020, 10, No. 7936.

(94) Demers, J. D.; Blum, J. D.; Brooks, S.; Donovan, P. M.; Riscassi, A.; Miller, C. L.; Zheng, W.; Gu, B. Hg isotopes reveal in-stream processing and legacy inputs in East Fork Poplar Creek, Oak Ridge, Tennessee, USA. Environ. Sci.: Processes Impacts 2018, 686.

(95) Chen, J.; Hintelmann, H.; Zheng, W.; Feng, X.; Cai, H.; Wang, Z.; Yuan, S.; Wang, Z. Isotopic evidence for distinct sources of mercury in lake waters and sediments. Chem. Geol. 2016, 426, 33-44.

(96) Sun, R.; Streets, D. G.; Horowitz, H. M.; Amos, H. M.; Liu, G.; Perrot, V.; Toutain, J.-P.; Hintelmann, H.; Sunderland, E. M.; Sonke, J. E. Historical (1850-2010) mercury stable isotope inventory from anthropogenic sources to the atmosphere. Elementa: Sci. Anthropocene 2016, 4, No. 000091.

(97) Wiederhold, J. G.; Cramer, C. J.; Daniel, K.; Infante, I.; Bourdon, B.; Kretzschmar, R. Equilibrium mercury isotope fractionation between dissolved $\mathrm{Hg}$ (II) species and thiol-bound $\mathrm{Hg}$. Environ. Sci. Technol. 2010, 44, 4191-4197.

(98) Jiskra, M.; Wiederhold, J. G.; Bourdon, B.; Kretzschmar, R. Solution speciation controls mercury isotope fractionation of $\mathrm{Hg}$ (II) sorption to goethite. Environ. Sci. Technol. 2012, 46, 6654-6662.

(99) Zhou, J.; Obrist, D.; Dastoor, A.; Jiskra, M.; Ryjkov, A. Vegetation uptake of mercury and impacts on global cycling. Nat. Rev. Earth Environ. 2021, 2, 269-284.

(100) Pourchet, M.; Mourguiart, P.; Pinglot, J.-F.; Preiss, N.; Argollo, J.; Wirmann, D. Sédimentation récente dans le lac Titicaca (Bolivie). C. R. Acad. Sci. Paris 1994, 319, 535-541.
(101) Cooke, C. A.; Wolfe, A. P.; Michelutti, N.; Balcom, P. H.; Briner, J. P. A Holocene Perspective on Algal Mercury Scavenging to Sediments of an Arctic Lake. Environ. Sci. Technol. 2012, 46, 71357141. 